\title{
Anthocyanin-Colored Microencapsulation Effects on Survival Rate of Lactobacillus rhamnosus GG, Color Stability, and Sensory Parameters in Strawberry Nectar Model
}

\author{
Mohamed K. Morsy ${ }^{1}$ (D) Osama M. Morsy ${ }^{2} \cdot$ Mohamed A. Abdelmonem $^{3} \cdot$ Rasha Elsabagh $^{4}$
}

Received: 24 May 2021 / Accepted: 1 January 2022 / Published online: 12 January 2022

(c) The Author(s) 2022

\begin{abstract}
Probiotic microencapsulation is a promising way to produce functional food, while their stability and sensory acceptability still a challenge. This study aims to enhance the functional properties of strawberry (Fragaria $\times$ ananassa, cultivar Camarosa) nectar and sensory acceptance using novel anthocyanin-colored microencapsulation of Lactobacillus rhamnosus. Four formulations (F1-F4) of coated materials (alginate, whey protein, and pullulan) integrated with anthocyanin pigment were used for encapsulation. The physical properties of microencapsulated probiotics (size, color, efficiency, stability, and survival rate) and quality parameters of nectar ( $\mathrm{pH}$, anthocyanin, and sensory acceptability) during 4 weeks of storage at 4 and 25 ${ }^{\circ} \mathrm{C}$ were evaluated. All formulations exhibited high encapsulation efficiency ( $\left.>89 \%\right)$, medium bead size (406-504 $\left.\mu \mathrm{m}\right)$, and proper color (red color). The microencapsulated cells were stable in simulated gastrointestinal and processing conditions (up $7 \log 10 \mathrm{CFU} \mathrm{mL} \mathrm{m}^{-1}$ ) compared to free cells. F4 (alginate $2 \%+$ anthocyanin $0.1 \%+$ whey protein $2 \%+$ pullulan $2 \%+$ cocoa butter $1 \%+$ L. rhamnosus $\mathrm{GG})$ showed the greatest viability in nectar during storage $\left(6.72 \log 10 \mathrm{CFU} \mathrm{mL}-1 / 4{ }^{\circ} \mathrm{C} / 4\right.$ weeks $)$,

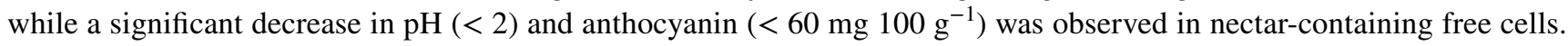
The sensory scores with a difference-preference test as exploratory and preliminary responses revealed that colored probiotic microcapsules enhanced the sensory characters (up to 4 weeks) and commercially accepted ( $>80 \%$ agreed) of strawberry nectar. Results demonstrated that anthocyanin-colored alginate-whey protein-pullulan matrix had the potential to enhance probiotic viability in functional nectar without negative impact.
\end{abstract}

Keywords Microencapsulation · Lactobacillus rhamnosus GG · Strawberry nectar · Quality parameters · Anthocyanin

\section{Introduction}

Strawberry (Fragaria $\times$ ananassa) nectar is considered one of the most important beverages, highly consumed in Egypt and worldwide (Yildiz \& Aadil, 2020). It is a source of vitamins, minerals, carbohydrates, dietary fibers, and antioxidants, moreover tasty, attractive to all ages, and refreshing (Salehi, 2020; Xu et al., 2021). However, they are lower in health benefits and functional properties than fruit juice (Pereda et al., 2020). Therefore, there is a growing interest in functional nectar by incorporation of healthy ingredients, such as probiotics and/or bioactive compounds (de Oliveira Vieira et al., 2020). According to Tripathi and Giri (2014), the probiotic foods represent approximately $60-70 \%$ of functional foods. Recently, the demand for probiotic products has gradually increased, the global market was about US\$ 377 million in 2016 and anticipated to expand US\$ 719 million by 2025 (Anand et al., 2018), while probiotic products 
estimated US\$ 61.1 billion in 2021 and anticipated to expand US\$ 91.1 billion by 2026 (MarketsandMarkets, 2018).

Probiotic such as Lactobacillus rhamnosus GG is one of the most important legalized clinical bacteria that is widely used as a probiotic culture in food products (Sohail et al., 2013). L. rhamnosus has many health benefits as it reduces the severity of diarrhea (Morales et al., 2016), improves the immunity (Costabile et al., 2017), and inhibits the adhesion of Salmonella enterica and Clostridium histolyticum (MedveĎová et al., 2008). However, there are several factors affecting the viability of probiotics such as temperature (Hao et al., 2021; Østlie et al., 2005), pH (Sohail et al., 2012), bile salt (Guerin et al., 2003), gastric juice (Praepanitchai et al., 2019), and food additives.

One of the ways to protect and improve the viability of probiotics in food products is the application of coating system using alginate (Mokarram et al., 2009). But, the maximum loading cells in the entrapped beads are restricted to $25 \%$ per volume due to weak mechanical strength (Liu et al., 2017). Another effective approach to overcome these limitations is using a multilayer technique encapsulation (Khorasani et al., 2017).

Encapsulation is a process in which the cells are held within a membrane to minimize cell injury and death (Celli et al., 2015). Recently, microencapsulation is receiving considerable interest as an approach for providing probiotic cells with a barrier against ingestion, storage, and food (Kailasapathy, 2009). Therefore, enhancing the viability of probiotic cells in gastrointestinal juice and during food processing is important for the microorganisms to reach sufficient numbers $\left(10^{6} \mathrm{CFU} \mathrm{g}^{-1}\right.$ or $\left.\mathrm{mL}^{-1}\right)$ of intestinal contents (Moumita et al., 2017) and have a positive impact on the host (Karimi et al., 2011). The encapsulation of probiotic cells has been investigated in various food products such as sausage (Bilenler et al., 2017), yogurt (El Kadri et al., 2018), soft cheese (Vasile et al., 2020), bread (Zhang et al., 2018), cereal bars (Bampi et al., 2016), chocolate (Malmo et al., 2013), and juice (Mokhtari et al., 2017). One study showed that chitosan-alginate encapsulation improved the survival of Lactobacillus rhamnosus in apple juice (Praepanitchai et al., 2019). Also, Krasaekoopt and Watcharapoka (2014) demonstrated that galacto-oligosaccharide-alginate microencapsulation kept the viability of Lactobacillus acidophilus and Lactobacillus casei at $10^{7} \mathrm{CFU} \mathrm{mL}^{-1}$ in fruit juice. Also, Rodrigues et al. (2012) found that microencapsulation in alginate with double coating protected Lactobacillus paracasei $\mathrm{L} 26$ over 50 days in orange juice.

Anthocyanins are water-soluble pigments, responsible for the red color in most fruits and vegetables (AlvarezSuarez et al., 2021; Giuffrè et al., 2017), as well as a good source of polyphenols and flavonoids as antioxidants (Gralec et al., 2019; Suriano et al., 2021). Anthocyanins have many components such as delphinidin-3-o-glucoside, cyanidin-3-o-glucoside, cyanidin-3-o-acetylglucoside, malvidin-3-o-glucoside, delphinidin-3-o-acetylglucoside, malvidin-3-o-p-coumarylglucoside, malvidin-3-o-acetylglucoside, petunidin-3-o-p-coumarylglucoside, peonin-3-o$p$-coumarylglucoside, petunidin-3-o-glucoside, peonidin3-o-glucoside, petunidin-3-o-acetylglucoside, and peonidin3-o-acetylglucoside (Giuffrè, 2013; Fan-Chiang \& Wrolstad, 2005). They are a permitted colorant in food and beverage products and has extensively boosted their market requirement (Belwal et al., 2020). Also, they have many health benefits such as prophylactic to cardiovascular disease, anti-inflammatory, anti-carcinogenic, anti-obesity, and antidiabetic (Yousuf et al., 2016).

Pullulan is a polysaccharide produced by Aureobasidium pullulans (Haghighatpanah et al., 2020); it is used as a coating material in food and pharmaceutical because of its water-soluble, tasteless, odorless, colorless, and heat-stable properties. Also, whey protein is widely used as a polymer for microencapsulation of bioactive compounds using different techniques (de Araújo Etchepare et al., 2020). Pullulan and whey protein mixtures have been studied to form edible films and coatings to reduce moisture loss and extend the shelf life in food applications (Gounga et al., 2008).

Previous studies did the best to develop probiotic microencapsulation in different functional food. While, anthocyanincolored microencapsulated probiotic bacteria within a single biocomposite matrix in fruit juices have not been studied yet. Most of the published researches focused on used capsule material, i.e., alginate (Rodrigues et al., 2012; Shinde et al., 2014), alginate-chitosan (De Prisco et al., 2017; Malmo et al., 2013), whey protein isolate-gum arabic (Bosnea et al., 2014), pectin-starch (Dafe et al., 2017), inulin (dos Santos et al., 2019), soy protein (González-Ferrero et al., 2020), and starch (Murúa-Pagola et al., 2021). However, few studies utilized pullulan in microencapsulation (Ma et al., 2021; Sun et al., 2021). There are no literatures related to the impact of juice additives and processing conditions on the variability of probiotic microcapsules. Also, the effect of probiotic microcapsules on the sensory acceptability of food products remains a challenge. Therefore, our research proposes to develop a protection system and attractive tools for simultaneously delivering these two bioactive compounds to the gastrointestinal tract. These results add evidence that comicroencapsulation of anthocyanins and probiotic bacteria may be considered as a suitable approach to develop functional compounds and value-added foods, with preventive attributes against diseases.

Therefore, the aim of this study was to (I) produce a functional strawberry ( $F . \times$ ananassa, cultivar Camarosa) nectar fortified with microencapsulated $L$. rhamnosus GG; (II) investigate the stability of probiotic microcapsules under gastrointestinal, thermal processing, and juice 
additives; and (III) evaluate the influence of $L$. rhamnosus GG microcapsules on quality parameters and sensory properties (difference-preference test) of strawberry nectar during storage.

\section{Materials and Methods}

\section{Chemicals and Additives}

Bile salt, sodium alginate, tri-sodium citrate, phosphate buffer, Tween $80, \mathrm{HCl}, \mathrm{NaOH}, \mathrm{KCl}, \mathrm{CaCl}_{2}$, anthocyanin, whey protein, porcine pepsin, and pancreatin were purchased from Sigma-Aldrich (St. Louis, MO, USA). Citric acid, sodium benzoate, potassium sorbate, and CMC (ElNaser Co., CairoEgypt), carmoisine, and strawberry flavor (Kamena Co., Cairo, Egypt), sugar, and cocoa butter were purchased from a local market in Cairo, Egypt. Pullulan was obtained from the Hayashibara Company (Okayama, Japan).

\section{Culture Activation}

The Lactobacillus rhamnosus GG (American Type Culture Collection [ATCC] 53,103; Manassas, VA, USA) culture was maintained on the MRS agar (MRS-A; Biolife, Italy). The bacteria were activated twice in MRS broth (MRS-B; Biolife, Italy) and incubated at $37^{\circ} \mathrm{C} / 48 \mathrm{~h}$. The cells were harvested using centrifugation (Thermo Fisher Scientific Megafuge 8R, UK) at $3500 \times g$ under-cooling for $10 \mathrm{~min}$. The pellets were washed twice with sterile peptone water $(0.1 \%$; BPW; Biolife, Italy), then re-suspended in $5 \mathrm{~mL}$ sterile BPW to the final population $7.5 \log _{10} \mathrm{CFU} \mathrm{mL} \mathrm{m}^{-1}$.

\section{Microencapsulation of Probiotic Bacteria}

The microencapsulation of probiotic bacteria was prepared according to the method described by Mokhtari et al. (2017) with some modifications. Briefly, different solutions of sodium alginate $(2 \% ; w / v)$, whey protein $(2$ or $3 \% ; w / v)$, and pullulan $(2 \% ; w / v)$ were dissolved in distilled water, then autoclaved $\left(121{ }^{\circ} \mathrm{C}\right.$ for $\left.15 \mathrm{~min}\right)$; after cooling, the anthocyanin $(0.1 \%$; $w / v)$ was added. The $5 \mathrm{~mL}$ of $L$. rhamnosus GG pellets $(\sim 7.5$ $\log _{10} \mathrm{CFU} \mathrm{mL} \mathrm{mL}^{-1}$ ) and cocoa butter-Tween $80(1 \% ; w / v)$ (core material) were suspended in $100 \mathrm{~mL}$ of sterile-colored alginate (wall material). The probiotic suspension was dispensed gently using a 5-mL syringe (Nipro, Japan) into $500 \mathrm{~mL}$ calcium chloride $(0.155 \mathrm{M})$ with stirring at $300 \mathrm{rpm}$ and held for 30 min for gelation. Afterward, the beads were harvested using filter paper (Whatman No. 4), then washed with sterilized distilled water, and kept subsequently in a sterile peptone solution $(0.1 \%)$ at $4{ }^{\circ} \mathrm{C}$ until use (Morsy \& Elsabagh, 2021).

\section{Preparation of Strawberry Nectar}

Strawberry (Fragaria $\times$ ananassa, cultivar Camarosa) concentrate $\left(65^{\circ} \mathrm{Brix}\right)$ was purchased from Döhler Co. (Giza, Egypt), then diluted for the preparation of strawberry nectar, according to the General Standards for Fruit Juices and Nectars (Codex, 2005). The nectar recipe was fruit juice $(40 \% ; v / v)$, citric acid $(0.3 \% ; w / v)$, preservatives $(0.1 \% ; w / v)$, carmoisine $(0.01 \% ; w / v)$, flavor $(0.05 \% ; v / v)$, CMC $(0.1 \% ; w / v)$, and sugar (TSS $7.5^{\circ}$ Brix). The nectar was placed in a glass bottle of $200 \mathrm{~mL}$ (Middle East Co. of glass, Cairo, Egypt). The nectar was divided depending on microcapsule supplementation into six groups as follows; first (FC; free cells [non-encapsulated]), second (F1; alginate $2 \%+$ anthocyanin $0.1 \%+L$. rhamnosus GG), third (F2; alginate $2 \%+$ anthocyanin $0.1 \%+$ cocoa butter $1 \%+$ L. rhamnosus $\mathrm{GG})$, fourth (F3; alginate $2 \%+$ anthocyanin $0.1 \%+$ whey protein $3 \%+$ cocoa butter $1 \%+L$. rhamnosus $\mathrm{GG}$ ), fifth (F4; alginate $2 \%+$ anthocyanin $0.1 \%+$ whey protein $2 \%$ + pullulan $2 \%+$ cocoa butter $1 \%+L$. rhamnosus $\mathrm{GG})$, and last one without cells $(\mathrm{C}$; control). All treatments were kept at $4 \pm 1{ }^{\circ} \mathrm{C}$ and $25 \pm 1{ }^{\circ} \mathrm{C}$ for 4 weeks. The nectar samples were checked at intervals $0,1,2,3$, and 4 weeks.

\section{Morphology, Bead Size, and Color}

The morphology of the microencapsulated beads (L. rhamnosus GG) was evaluated using scanning electron microscopy (SEM; JSM-6510-LA Ja, Japan). The distribution of microbead size in dispersion medium was measured by a Malvern Mastersizer 3000 (Malvern Instruments, Germany) (de Araújo Etchepare et al., 2020). The color intensity $L^{*}, a^{*}$, and $b^{*}$ of microencapsulated beads was measured by a Minolta spectrophotometer (model: CM508d Minolta Corp., Ramsey, NJ, USA). The instrument values are $L^{*}$ (lightness), $a^{*}$ (redness/greenness), and $b^{*}$ (yellowness/blueness). The chroma $\left(C^{*}\right)$ were calculated by Eq. (1).

$C^{*}=\sqrt{a *^{2}+b *^{2}}$

\section{Encapsulation Efficiency}

The EE (\%) was determined using the method described by Afzaal et al. (2019) with slight modifications. The microencapsulated beads were centrifuged at $3000 \times g$ (Thermo Fisher Scientific Megafuge 8R, UK) to remove the thin film of peptone solution. A $10 \mathrm{~g}$ of microencapsulated beads was dissolved in $100 \mathrm{~mL}$ phosphate buffer 
(pH 7.2; $37{ }^{\circ} \mathrm{C} ; 60 \mathrm{~min}$ ), and thereafter, viable bacterial cells were diluted and counted on MRS agar (expressed as $\left.\left[\log _{10} \mathrm{CFU} \mathrm{g}^{-1}\right]\right)$. The EE (\%) was calculated according to Eq. (2).

$E E(\%)=100 \frac{M}{M 0}$

where $M$ is the number of viable cells $\left(\log _{10} \mathrm{CFU} \mathrm{\textrm {g } ^ { - 1 }}\right)$ released from the microcapsules and $M 0$ is the number of free viable cells $\left(\log _{10} \mathrm{CFU} \mathrm{g}^{-1}\right)$ before the encapsulation process.

\section{Stability of Microencapsulated L. rhamnosus GG}

\section{Heat Treatments and Storage Conditions}

The stability of L. rhamnosus GG encapsulated beads against different heat treatments was assessed as described by (Zhang et al., 2015) with slight modifications. A $10 \mathrm{~g}$ of microparticles and free cells was transferred to $90 \mathrm{~mL}$ of peptone water $(0.1 \% ; w / v)$ in falcon tubes. These contents were exposed to various temperatures in a water bath (Thermo Scientific, UK), i.e., $25 \pm 1{ }^{\circ} \mathrm{C}$ for $60 \mathrm{~min}$ and $72 \pm 1{ }^{\circ} \mathrm{C}$ for $15 \mathrm{~min}$ as well as refrigeration temperature $4 \pm 1{ }^{\circ} \mathrm{C}$ for $60 \mathrm{~min}$. All aliquots were collected, and probiotic viable cells were counted on MRS agar (as in the "Enumeration of Entrapped L. rhamnosus GG Cells" section).

\section{Juice Additives}

The viability of the microencapsulated $L$. rhamnosus GG in different juice additives was evaluated. Ten grams of microparticles and free cells was transferred to $90 \mathrm{~mL}$ of sugar solution $\left(7.5^{\circ}\right.$ Brix $)$, citric acid $0.3 \%$, sodium benzoate $0.1 \%$, potassium sorbate $0.1 \%$, carmoisine $0.01 \%$, strawberry flavor $0.05 \%$, CMC $0.1 \%$, and mix of additives. The probiotic viable cells were counted on MRS agar.

\section{Simulated Gastrointestinal Conditions}

The viability of $L$. rhamnosus GG under simulated gastric juice (SGJ) was determined according to Krasaekoopt et al. (2008). A $10 \mathrm{~g}$ of freshly prepared beads and free cells was placed in $90 \mathrm{~mL}$ of sterile SGJ $(0.08 \mathrm{M} \mathrm{HCl}$ containing $0.2 \%$ $\mathrm{NaCl}, \mathrm{pH} 1.5$ ), then incubated at $37{ }^{\circ} \mathrm{C}$ for $0,30,120$, and 240 min with agitation at $50 \mathrm{rpm}$ using a shaker incubator (New Brunswick ${ }^{\mathrm{TM}}$ Excella ${ }^{\circledR}$ E25/E25R, USA). The beads were collected by filtration (Whatman No. 4), and free cells were collected by centrifugation under-cooling (Thermo Fisher Scientific Megafuge 8R, UK). Both beads and free cells were placed individually in $90 \mathrm{~mL}$ of sterile simulated intestinal juice (SIJ; $0.05 \mathrm{M} \mathrm{KH}_{2} \mathrm{PO}_{4}, 0.6 \%$ bile salt, $\mathrm{pH} 7.4$ ), then incubated at $37^{\circ} \mathrm{C}$ for $150 \mathrm{~min}$. The viable bacterial cells were enumerated in MRS medium.

\section{Enumeration of Entrapped L. rhamnosus GG Cells}

Ten grams of $L$. rhamnosus $\mathrm{GG}$ beads was placed into 90 $\mathrm{mL}$ of $0.1 \mathrm{M}$ sterile phosphate buffer $(\sim \mathrm{pH} 7)$ and stomached for 10-15 min (Chaikham, 2015). Certainly, tenfold serial dilutions were done with sterile $0.1 \%$ peptone solution. $L$. rhamnosus was enumerated on MRS agar (Biolife, Milan, Italy) at $37^{\circ} \mathrm{C}$ for $48-72 \mathrm{~h}$ under anaerobic conditions; also free cells enumerated similarly. The populations converted to $\log _{10}$ and expressed as $\log _{10} \mathrm{CFU} \mathrm{g}^{-1}$ or $\mathrm{mL}^{-1}$.

\section{$\mathrm{pH}$ and Anthocyanin in Strawberry Nectar}

The $\mathrm{pH}$ value of strawberry $(F . \times$ ananassa, cultivar Camarosa) nectar was carried out using a digital $\mathrm{pH}$ meter (Consort, model P107, Belgium). Anthocyanin content was determined using the spectrophotometer method (CE 599 Universal, USA) at $535 \mathrm{~nm}$ (AOAC, 2016).

\section{Sensory Evaluation and Questionnaire}

The sensory evaluation was done using a differencepreference test as exploratory and preliminary responses. Ten-member trained panelists aged (20-45 years) from the Department of Food Technology, Benha University, asked to evaluate the strawberry nectar containing free cells and microencapsulated probiotic during the refrigerated storage. The nectar samples were homogenous, served in $50 \mathrm{~mL}$ covered plastic cups coded with 3 -digit random numbers. The panelists were judged to evaluate the nectar samples using a 7-point hedonic scale for color, odor, taste, texture, and overall acceptability with scores being as follows: $7=$ like extremely, $6=$ like moderately, $5=$ like slightly, $4=$ neither like nor a dislike, $3=$ dislike slightly, $2=$ dislike moderately, and $1=$ dislike extremely (Krasaekoopt \& Kitsawad, 2010). While, the questionnaire was done according to Van der Merwe et al. (2014) with minor modification. The questionnaire performed by juice companies in Egypt using 11 team or committee (every committee included 15 member; total 165 member); these committees from trained panelists at different departments in the company such as production staff, quality staff, and R\&D staff. The panelists asked through a questionnaire to evaluate the strawberry nectar containing microencapsulated probiotic using a 3-point scale ( $3=$ agree, $2=$ undecided, and $1=$ disagree $)$ and expressed as a percentage. 


\section{Statistical Analysis}

The obtained data were analyzed using SPSS software (Version 18 , Chicago, IL, USA) and presented as mean \pm SD. One-way analysis of variance (ANOVA) and Tukey's tests at $P<0.05$ of means were carried out. All experiments in the study were performed in triplicate, while the sensory evaluation (difference-preference test) was run with 10 panelists and questionnaire 11-juice companies. Two factors (free cells and microencapsulated) of probiotics were applied. For microcapsules, evaluation and analysis (morphological, bead size, encapsulation efficiency, and stability) were done. Strawberry nectar analysis $(\mathrm{pH}$, anthocyanin, sensory properties, and questionnaire) and factorial design ANOVA with two factors, six treatments (control, FC, F1, F2, F3, F4) and storage time with five points at $0,1,2,3$, and 4 weeks, were applied for each parameter (Steel et al., 1980).

\section{Results and Discussion}

\section{Morphology, Size, and Color of Microparticles}

The microcapsule morphology for different formulations (F1-F4), i.e., alginate, whey protein, and pullulan, showed spherical, uniform, smooth, and free from cracks under scanning electron microscopy. Results revealed that formula F4, quite spherical shape, red color, and homogenous probiotic cells, spread throughout the microcapsules compared to other formulations. Therefore, sodium alginate $(2 \% ; w / v)$ in combination with hydrocolloids, i.e., whey protein and/ or pullulan, had formed a good matrix for protective layers of microencapsulated probiotic. To verify the alginate presence (wall material) and microorganisms (core material) in the entire interior of the microbeads, characterizing it as a matrix, verifying that the core material is not only sited in the center but also inside the beads (de Araújo Etchepare et al., 2020). The hydrocolloids and alginate multilayer did not change the appearance of the analyzed microcapsules (Fig. 1). From scanning electron microscopy (SEM) images, it was noticed that treatments F1 and F2 have very few pores with potential penetration on the surface of the beads (Fig. 1). While other formulations (F3 and F4) revealed that beads free from pores may be due to hydrocolloid compounds and were integrated into the polymer network, and beads entrapped the cells. Similar findings were reported by Nami et al. (2020) who found that microencapsulated Lactococcus lactis ABRIINW-N19 with alginate-Persian gum (ALG-PG) exhibited spherical shape beads. The spherically shaped microcapsules have advantages such as ease of production, consumption, application, and packaging. Other studies confirmed that spherical beads with multilayer were observed in alginate-psyllium (Zeashan et al., 2020)

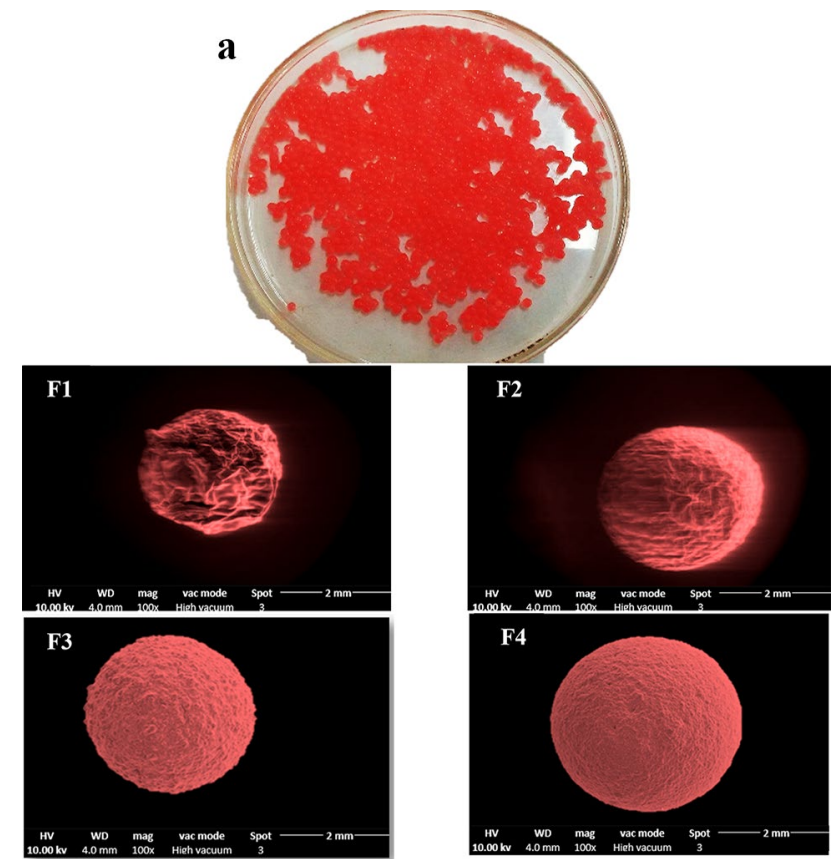

Fig. 1 Photo of colored microcapsules of L. rhamnosus GG (a) and scanning electron microscopy (SEM) images of encapsulated L. rhamnosus $\mathrm{GG}$ at different formulations (F1-F4). F1: alginate $2 \%+$ anthocyanin $0.1 \%+$ L. rhamnosus GG), F2: alginate $2 \%+$ anthocyanin $0.1 \%+$ cocoa butter $1 \%+$ L. rhamnosus GG), F3: alginate $2 \%+$ anthocyanin $0.1 \%+$ whey protein $3 \%+$ cocoa butter $1 \%+L$. rhamnosus GG), F4: alginate $2 \%+$ anthocyanin $0.1 \%+$ whey protein $2 \%+$ pullulan $2 \%+$ cocoa butter $1 \%+L$. rhamnosus $\mathrm{GG})$

and alginate-chitosan (Praepanitchai et al., 2019; Xu et al., 2016).

As shown in Table 1, the mean size of $L$. rhamnosus GG microcapsules was ranged between 406 and $504 \mu \mathrm{m}$. The maximum bead size was in $\mathrm{F} 4$, while the minimum was recorded in F1. A significant difference in particle size $(P$ $<0.05)$ was observed between all formulations. However, alginate multilayer has the potential to keep residence at the application site as a juice supplement delivery system. The variation in bead size could be related to (i) hydration capacity of the polysaccharides (pullulan) through hydrogen bonds (Boudou et al., 2010), (ii) combination between whey protein and alginate that forms viscose solution effect of the size (Zeashan et al., 2020), (iii) technological process such as varying agitation rate and water/oil ratio, and (iv) structural configuration of the microcapsule layers. Similar findings have been reported by Praepanitchai et al. (2019) who found that encapsulation material and multilayer type affect the bead size.

The color parameters, i.e., $L^{*}, a^{*}$, and $c^{*}$, of the multilayer microparticles are shown in Table 1. All the microparticles showed a red color (as color reference of strawberry nectar $40 \%$ fruit juice), indicating a good homogeneity. No significant difference $(P>0.05)$ in color was recorded 
Table 1 Bead size, color, and encapsulation efficiency of the L. rhamnosus GG microparticles with different multilayer (mean \pm SD)

\begin{tabular}{|c|c|c|c|c|c|c|c|}
\hline \multirow[t]{2}{*}{ Formula } & \multirow[t]{2}{*}{ Bead size $(\mu \mathrm{m})$} & \multicolumn{3}{|c|}{ Tristimulus color values } & \multicolumn{3}{|c|}{ Encapsulation efficiency (EE; \%) } \\
\hline & & $L^{*}$ & $a^{*}$ & $C^{*}$ & $\begin{array}{l}\text { Numbers before } \\
\text { encapsulation }\left(\log _{10}\right. \\
\left.\text { CFU g }{ }^{-1}\right)\end{array}$ & $\begin{array}{l}\text { Numbers after } \\
\text { encapsulation }\left(\log _{10}\right. \\
\left.\text { CFU g } g^{-1}\right)\end{array}$ & $\mathrm{EE} \%$ \\
\hline $\mathrm{F} 1$ & $406.00 \pm 19.31 \mathrm{~d}$ & $30.94 \pm 0.71 \mathrm{a}$ & $39.27 \pm 0.29 \mathrm{a}$ & $49.99 \pm 0.77 \mathrm{a}$ & $7.83 \pm 0.15 \mathrm{a}$ & $7.05 \pm 0.17 \mathrm{~d}$ & $89.95 \pm 0.91 \mathrm{~d}$ \\
\hline $\mathrm{F} 2$ & $425.33 \pm 13.87 \mathrm{c}$ & $31.11 \pm 0.28 \mathrm{a}$ & $39.92 \pm 0.35 \mathrm{a}$ & $50.61 \pm 0.45 \mathrm{a}$ & $7.83 \pm 0.15 \mathrm{a}$ & $7.20 \pm 0.12 \mathrm{c}$ & $91.87 \pm 0.23 \mathrm{c}$ \\
\hline F3 & $454.67 \pm 13.32 b$ & $31.50 \pm 1.08 \mathrm{a}$ & $40.03 \pm 0.62 \mathrm{a}$ & $50.94 \pm 1.24 \mathrm{a}$ & $7.83 \pm 0.15 \mathrm{a}$ & $7.41 \pm 0.14 b$ & $94.66 \pm 0.69 \mathrm{~b}$ \\
\hline $\mathrm{F} 4$ & $504.00 \pm 22.34 \mathrm{a}$ & $31.67 \pm 0.73 \mathrm{a}$ & $40.09 \pm 0.45 \mathrm{a}$ & $51.09 \pm 0.86 \mathrm{a}$ & $7.83 \pm 0.15 \mathrm{a}$ & $7.72 \pm 0.11 \mathrm{a}$ & $98.59 \pm 0.41 \mathrm{a}$ \\
\hline
\end{tabular}

F1: alginate $2 \%+$ anthocyanin $0.1 \%+L$. rhamnosus GG), F2: alginate $2 \%+$ anthocyanin $0.1 \%+$ cocoa butter $1 \%+L$. rhamnosus GG, F3: alginate $2 \%+$ anthocyanin $0.1 \%+$ whey protein $3 \%+$ cocoa butter $1 \%+L$. rhamnosus GG, F4: alginate $2 \%+$ anthocyanin $0.1 \%+$ whey protein $2 \%+$ pullulan $2 \%+$ cocoa butter $1 \%+L$. rhamnosus GG. $n=3$. Same small letter indicates that there is no significant difference between any two means "in the same column" $(P>0.05)$

$L^{*}$ lightness, $a *$ redness/greenness, $C *$ chroma, $E E$ encapsulation efficiency

between all formulations. The color of microbeads was very parallel to strawberry nectar. This red color of microparticles was due to anthocyanin pigment and matched with the structure of strawberry nectar.

\section{Encapsulation Efficiency}

Table 1 shows that the encapsulation efficiency of different formulations of the alginate microcapsule was $89.95 \%$, 91.87, 94.66, and $98.59 \%$ for F1, F2, F3, and F4, respectively. According to the outcomes, there were critical contrasts for encapsulation efficiency in all these four formulations. High EE ( $>98 \%$ ) in F4 indicated successful multilayer entrapping of viable cells in prepared beads. Consequently, efficient probiotic viable cells $\left(7.72 \log _{10} \mathrm{CFU} \mathrm{g}{ }^{-1}\right.$ ) could be released at the site of impact. As indicated in the structure of microbeads, the core material and multilayer wall were hydrophobic/hydrophilic $(O / W)$, respectively; thus, the phospholipid-based multilayer acted as a reservoir for viable cells. These results were in agreement with those reported by de Araújo Etchepare et al. (2020) who found that better microcapsules contain alginate and whey protein because of their functional properties and direct impact on the encapsulation efficiency. Another study by Yasmin et al. (2019) explained that the microparticle containing WPC and pectin as a wall material demonstrated high $\mathrm{EE}(>85 \%)$ and have a protective impact on bacterial cells.

\section{Assessment of the Survival L. rhamnosus GG Microencapsulated During Heat Treatments and Storage Conditions}

Probiotic bacteria must survive in different processing temperatures to be beneficial and remain viable in food products. The survival of $L$. rhamnosus free cells and encapsulated was evaluated under different heat treatments at 72,25 , and
$4{ }^{\circ} \mathrm{C}$ (Table 2). A significant difference $(P<0.05)$ in the stability of microcapsule formulations at different temperatures was found. Generally, a slight decrease in the number of bacterial cells at refrigeration and ambient temperature was observed. However, the free cells (FCs) were more sensitive to thermal shock than microencapsulated cells at $72{ }^{\circ} \mathrm{C}$. The FC was unviable when exposed to pasteurization temperature $\left(72{ }^{\circ} \mathrm{C}, 15 \mathrm{~min}\right)$. While, bead encapsulated cells were $5.88,6.18,6.88$, and $7.31 \log _{10} \mathrm{CFU} \mathrm{g}{ }^{-1}$, in F1, F2, F3, and F4, respectively. The formulations F3 and F4 showed significantly higher resistance at $72{ }^{\circ} \mathrm{C}$ compared to the others, with a reduction of 0.71 and $0.28 \log _{10} \mathrm{CFU} \mathrm{g}{ }^{-1}$, respectively. This may be because the encapsulated probiotic cells using alginate, whey protein, and/or pullulan can protect the cells from thermal pasteurization. These results were promising and in agreement with those reported by Rather et al. (2017) who found that microencapsulated probiotics by double alginate microencapsulation have higher stability to heat treatment $\left(75^{\circ} \mathrm{C}\right.$ for $\left.10 \mathrm{~min}\right)$. The obtained results are also in line with the experiments carried out by Zeashan et al. (2020). Thus, the survival of the probiotic microcapsules upon exposure to a thermal process depends on many factors, i.e., encapsulation technique, the architecture of microcapsules, and suitable polymers (Vemmer \& Patel, 2013).

\section{Viability of Encapsulated L. rhamnosus GG Exposed to Juice Additives}

Many additives are placed in the nectar during the processing to enhance its quality and shelf life. The impact of juice additives, i.e., sugar, citric acid, sodium benzoate, potassium sorbate, carmoisine, flavor, and CMC, on the survival of free and encapsulated $L$. rhamnosus GG was evaluated (Table 2). Results demonstrated a significant difference $(P<0.05)$ in the stability of probiotic microcapsule formulations in juice 
Table 2 Stability and viability of free and encapsulated L. rhamnosus GG on thermal processing and juice additives (mean \pm SD)

\begin{tabular}{|c|c|c|c|c|c|c|c|c|}
\hline \multirow[t]{2}{*}{ Factors } & \multirow[t]{2}{*}{ Items } & \multirow[t]{2}{*}{ Function } & \multicolumn{6}{|c|}{ L. rhamnosus GG cells } \\
\hline & & & Initial & $\mathrm{FC}$ & $\mathrm{F} 1$ & $\mathrm{~F} 2$ & F3 & $\mathrm{F} 4$ \\
\hline \multirow{3}{*}{$\begin{array}{l}\text { Thermal con- } \\
\text { ditions }\end{array}$} & $4{ }^{\circ} \mathrm{C}$ & Refrigeration & $7.67 \pm 0.16 \mathrm{aA}$ & $5.38 \pm 0.17 \mathrm{eA}$ & $6.11 \pm 0.16 \mathrm{dA}$ & $6.51 \pm 0.09 \mathrm{cA}$ & $7.26 \pm 0.12 \mathrm{bA}$ & $7.46 \pm 0.22 \mathrm{aA}$ \\
\hline & $25^{\circ} \mathrm{C}$ & $\begin{array}{l}\text { Ambient } \\
\text { condition }\end{array}$ & $7.72 \pm 0.18 \mathrm{aA}$ & $5.21 \pm 0.15 \mathrm{eA}$ & $5.99 \pm 0.15 \mathrm{~dB}$ & $6.41 \pm 0.07 \mathrm{cA}$ & $7.12 \pm 0.10 \mathrm{bB}$ & $7.40 \pm 0.17 \mathrm{aA}$ \\
\hline & $72{ }^{\circ} \mathrm{C}$ & Pasteurization & $7.59 \pm 0.15 \mathrm{aA}$ & $0.0 \mathrm{fB}$ & $5.88 \pm 0.14 \mathrm{eB}$ & $6.18 \pm 0.14 \mathrm{~dB}$ & $6.88 \pm 0.17 \mathrm{cC}$ & $7.31 \pm 0.10 \mathrm{bB}$ \\
\hline \multirow[t]{8}{*}{ Juice additives } & $\begin{array}{l}\text { Sugar solution } \\
7.5^{\circ} \mathrm{Bx}\end{array}$ & Sweeteners & $7.63 \pm 0.09 \mathrm{aA}$ & $4.53 \pm 0.23 \mathrm{~dB}$ & $5.81 \pm 0.14 \mathrm{cB}$ & $6.29 \pm 0.15 b C$ & $7.37 \pm 0.11 \mathrm{aA}$ & $7.54 \pm 0.05 \mathrm{aA}$ \\
\hline & $\begin{array}{l}\text { Citric acid } \\
0.3 \%\end{array}$ & Acidify & $7.73 \pm 0.15 \mathrm{aA}$ & $4.17 \pm 0.09 \mathrm{dC}$ & $6.36 \pm 0.16 \mathrm{cA}$ & $6.57 \pm 0.09 \mathrm{cB}$ & $7.28 \pm 0.06 \mathrm{bA}$ & $7.56 \pm 0.08 \mathrm{aA}$ \\
\hline & $\begin{array}{l}\text { Sodium ben- } \\
\text { zoate } 0.1 \%\end{array}$ & Antimicrobial & $7.65 \pm 0.15 \mathrm{aA}$ & $0 \pm 0.11 \mathrm{dE}$ & $5.77 \pm 0.19 \mathrm{cB}$ & $6.27 \pm 0.09 \mathrm{bC}$ & $6.40 \pm 0.17 \mathrm{bB}$ & $7.43 \pm 0.12 \mathrm{aA}$ \\
\hline & $\begin{array}{l}\text { Potassium } \\
\text { sorbate } 0.1 \%\end{array}$ & Antimicrobial & $7.57 \pm 0.08 \mathrm{aA}$ & $2.64 \pm 0.20 \mathrm{eD}$ & $5.80 \pm 0.19 \mathrm{~dB}$ & $6.37 \pm 0.08 \mathrm{cB}$ & $6.96 \pm 0.25 \mathrm{bB}$ & $7.46 \pm 0.16 \mathrm{aA}$ \\
\hline & $\begin{array}{l}\text { Carmoisine } \\
0.01 \%\end{array}$ & Color & $7.71 \pm 0.11 \mathrm{aA}$ & $6.61 \pm 0.17 \mathrm{eA}$ & $6.47 \pm 0.24 \mathrm{dA}$ & $7.03 \pm 0.36 \mathrm{cA}$ & $7.45 \pm 0.17 \mathrm{bA}$ & $7.61 \pm 0.15 \mathrm{aA}$ \\
\hline & $\begin{array}{l}\text { Strawberry } \\
\quad \text { flavor } 0.05 \%\end{array}$ & Flavor & $7.64 \pm 0.09 \mathrm{aA}$ & $6.50 \pm 0.11 \mathrm{dA}$ & $6.66 \pm 0.15 \mathrm{dA}$ & $7.10 \pm 0.22 \mathrm{cA}$ & $7.43 \pm 0.15 \mathrm{bA}$ & $7.59 \pm 0.13 \mathrm{aA}$ \\
\hline & CMC $0.1 \%$ & Thickener & $7.55 \pm 0.10 \mathrm{aA}$ & $6.72 \pm 0.15 \mathrm{cA}$ & $6.88 \pm 0.11 \mathrm{cA}$ & $7.22 \pm 0.17 \mathrm{bA}$ & $7.40 \pm 0.13 \mathrm{aA}$ & $7.48 \pm 0.07 \mathrm{aA}$ \\
\hline & $\begin{array}{c}\text { Additives } \\
\text { mixture }\end{array}$ & Quality & $7.77 \pm 0.13 \mathrm{aA}$ & $0 \pm 0.10 \mathrm{eE}$ & $5.68 \pm 0.31 \mathrm{dA}$ & $6.21 \pm 0.12 \mathrm{cC}$ & $6.52 \pm 0.10 \mathrm{bB}$ & $7.61 \pm 0.16 \mathrm{aA}$ \\
\hline
\end{tabular}

FC free cell (non-encapsulated), F1: alginate $2 \%+$ anthocyanin $0.1 \%+L$. rhamnosus GG), F2: alginate $2 \%+$ anthocyanin $0.1 \%+$ cocoa butter $1 \%+$ L. rhamnosus GG, F3: alginate $2 \%+$ anthocyanin $0.1 \%+$ whey protein $3 \%+$ cocoa butter $1 \%+$ L. rhamnosus GG, F4: alginate $2 \%+$ anthocyanin $0.1 \%+$ whey protein $2 \%$ + pullulan $2 \%+$ cocoa butter $1 \%+L$. rhamnosus GG. Same small letter indicates that there is no significant difference between any two means "in the same row" $(P>0.05)$. Same capital letter indicates that there is no significant difference between any two means "in the same column" $(P>0.05) . n=3$

additives. Generally, the FC of probiotics was decreased after exposure to most juice additives, while being absent after exposure to sodium benzoate $(0.1 \%)$. On the other hand, the microencapsulated cells in beads were more resistant to all juice additives. The formulations F3 and F4 were higher stability against juice additives; this may be related to the materials and/or multilayer of differing chemical nature which provide better tolerance to probiotics microcapsules, mainly with sodium benzoate and potassium sorbate. Therefore, the whey protein and polymer multilayer inserted into the probiotic cell can maintain the bacterial structure better than the free cells or even with a polymeric coating, thus improving the stability against additives (de Araújo Etchepare et al., 2020).
Table 3 Survival of free and encapsulated L. rhamnosus GG under simulated gastrointestinal conditions (SGC), in 0, 30, 120, and $240 \mathrm{~min}($ mean \pm SD)

\begin{tabular}{llllll}
\hline Time (min.) & \multicolumn{5}{l}{ L. rhamnosus GG cells } \\
\cline { 2 - 6 } & FC & F1 & F2 & F3 & F4 \\
\hline 0 & $7.64 \pm 0.17 \mathrm{aA}$ & $7.57 \pm 0.25 \mathrm{aA}$ & $7.61 \pm 0.13 \mathrm{aA}$ & $7.88 \pm 0.09 \mathrm{aA}$ & $7.74 \pm 0.17 \mathrm{aA}$ \\
30 & $4.80 \pm 0.18 \mathrm{cB}$ & $6.34 \pm 0.16 \mathrm{bB}$ & $6.67 \pm 0.13 \mathrm{bB}$ & $7.21 \pm 0.19 \mathrm{aA}$ & $7.54 \pm 0.27 \mathrm{aA}$ \\
120 & $3.52 \pm 0.24 \mathrm{eC}$ & $5.54 \pm 0.15 \mathrm{dC}$ & $6.34 \pm 0.26 \mathrm{cB}$ & $6.87 \pm 0.12 \mathrm{bB}$ & $7.26 \pm 0.13 \mathrm{aB}$ \\
240 & $1.89 \pm 0.15 \mathrm{eD}$ & $3.96 \pm 0.21 \mathrm{dD}$ & $5.11 \pm 0.26 \mathrm{cC}$ & $6.79 \pm 0.10 \mathrm{bB}$ & $7.11 \pm 0.26 \mathrm{aB}$ \\
Reduction rate (\%) & 75.26 & 47.69 & 32.85 & 13.83 & 8.14 \\
\hline
\end{tabular}

$F C$ free cell (non-encapsulated), F1: alginate $2 \%+$ anthocyanin $0.1 \%+L$. rhamnosus $\mathrm{GG}$ ), F2: alginate $2 \%+$ anthocyanin $0.1 \%+$ cocoa butter $1 \%+L$. rhamnosus GG, F3: alginate $2 \%+$ anthocyanin $0.1 \%+$ whey protein $3 \%+$ cocoa butter $1 \%+L$. rhamnosus GG, F4: alginate $2 \%+$ anthocyanin $0.1 \%+$ whey protein $2 \%+$ pullulan $2 \%+$ cocoa butter $1 \%+L$. rhamnosus GG. Same small letter indicates that there is no significant difference between any two means "in the same row" $(P>0.05)$. Same capital letter indicates that there is no significant difference between any two means "in the same column" $(P>0.05) . n=3$ 


\section{Stability and Viability of Free and Encapsulated L. rhamnosus GG Exposed to Simulated Gastrointestinal Conditions}

In order to provide health benefits and functional properties, probiotics must be able to be viable under gastrointestinal conditions (between $10^{6}$ and $0^{8} \mathrm{CFU} \mathrm{g^{-1 }}$ of intestinal content) (Mays \& Nair, 2018). As shown in Table 3, the count of free culture and probiotic microparticles at the beginning of the experiment ranged from 7.57 to $7.88 \log _{\mathrm{CFU} \mathrm{g}}{ }^{-1}$. However, the free cell count indicated a higher reduction of (5.75 $\left.\log \mathrm{CFU} \mathrm{g}{ }^{-1} ; 75.26 \%\right)$ after exposure to simulated gastrointestinal, whereas viable count of $L$. rhamnosus encapsulated in formulations, F1, F2, F3, and F4 showed a decrease of (3.61 log CFU g $\left.{ }^{-1} ; 47.69 \%\right),\left(2.5 \log \mathrm{CFU} \mathrm{g}^{-1} ; 32.85 \%\right)$, $\left(1.09 \log \mathrm{CFU} \mathrm{g}^{-1} ; 13.83 \%\right)$, and $\left(0.63 \log \mathrm{CFU} \mathrm{g}^{-1} ; 8.14 \%\right)$, respectively. These results revealed that multilayer encapsulation has a positive protection and shielding impact toward probiotics in simulated gastrointestinal. The formulations F2, F3, and F4 showed higher survive ability than F1 after exposure to simulated gastrointestinal conditions $(P<0.05)$, but the best outcome was noticed in F4. Similar findings and loss of free cells in simulated gastrointestinal conditions were in agreement with investigations by Gandomi et al. (2016) and Nami et al. (2020). The use of proteins and polysaccharides in the microencapsulation process provided substantially better protection. Previous studies by $\mathrm{Su}$ et al. (2018) and de Araújo Etchepare et al. (2020) have reported that the use of polymer as an encapsulating wall material provided better protection to probiotic cells as compared to free cultures when exposed to gastrointestinal conditions. Whey protein has been exhibited to be a proper and efficient wall material because of its buffering ability and tolerance of low $\mathrm{pH}$. Also, the pullulan has high protection ability in microencapsulated cells that may be due to higher density and strong structure (Ma et al., 2021).

\section{Viability of Free and Encapsulated L. rhamnosus GG in Strawberry Nectar After Storage}

Table 4 shows the viable count of free cells and microbeads $L$. rhamnosus GG in strawberry $(F$. $\times$ ananassa, cultivar Camarosa) nectar after 4 weeks of storage. The viable cell counts of $L$. rhamnosus $\mathrm{GG}$ decreased $(P<0.05)$ after 4 weeks of storage at both 4 and $25^{\circ} \mathrm{C}$ by $57.9 \%$ and $78.63 \%$, respectively. The extreme decrease of free $L$. rhamnosus $\mathrm{GG}$ cell number in apple juice $\sim 87.5 \%$ after 4 weeks of storage was also confirmed by Ding and Shah (2008). Results demonstrated that the free L. rhamnosus GG reduced $100 \%(P<$ $0.05)$ under the simulated gastrointestinal at both 4 and 25 ${ }^{\circ} \mathrm{C}$ for 4 weeks of storage. These results indicated that the $L$. rhamnosus GG was sensitive to the conditions in strawberry nectar and during the gastrointestinal transit. These findings were in agreement with those reported by Lai et al. (2020) where free L. rhamnosus GG cells in hawthorn berry tea reduced by $100 \%$ after exposure to gastrointestinal for 120 min. Another report by Chávarri et al. (2012) found 100\% reduction of free Lactobacillus gasseri and Bifidobacterium bifidum cells after exposing to gastrointestinal.

The viability of microencapsulated L. rhamnosus GG formulations was quite stable in strawberry nectar and even after exposure to simulate gastrointestinal. Formulations F1, F2, F3, and F4 showed a viability decrease of $53.07,51.04,19.97$, and $8.48 \%$, respectively, at $25^{\circ} \mathrm{C}$ and $41.31,36.1,18.05$, and $6.81 \%$, respectively, at $4{ }^{\circ} \mathrm{C}$.

Among the formulations, the F4 microbeads stored at $4{ }^{\circ} \mathrm{C}$ had the lowest reduction of $13.62 \%$ when compared to other formulations up to 4 weeks of storage. Moreover, encapsulated L. rhamnosus GG with alginate-whey protein-pullulan formulations (F3 and F4) provided better protection of entrapped L. rhamnosus GG cells, with 6.52 $\log \mathrm{CFU} \mathrm{mL} \mathrm{m}^{-1}$ and $6.72 \log \mathrm{CFU} \mathrm{mL} \mathrm{m}^{-1}$ maintained count for 25 and $4{ }^{\circ} \mathrm{C}$, respectively, at the end of 4 -week storage. This indicated that the incorporation of pullulan into the encapsulating material exhibited a synergistic effect that protects the cells against the low $\mathrm{pH}$ of strawberry nectar. A previous study by Gandomi et al. (2016) reported that entrapped $L$. rhamnosus $\mathrm{GG}$ cells in apple juice exhibited higher viable counts after 3 months of storage at $4{ }^{\circ} \mathrm{C}$ than $25^{\circ} \mathrm{C}$.

\section{Physical Properties of Strawberry Nectar Fortified with Probiotic Microcapsules}

\section{pH Value}

In Fig. 1, the initial $\mathrm{pH}$ value of the strawberry $(F . \times$ ananassa, cultivar Camarosa) nectar was 3.57; then, the $\mathrm{pH}$ decreased significantly $(P<0.05)$ in most treatments that contained probiotic cells during storage. It was observed that the $\mathrm{pH}$ of strawberry nectar containing free cells decreased to 1.99 and 1.57 after 4 weeks of storage at 4 and $25{ }^{\circ} \mathrm{C}$, respectively, while the $\mathrm{pH}$ of strawberry nectar containing formulations $(\mathrm{F} 1$ and $\mathrm{F} 2)$ significantly $(P<0.05)$ showed a decline (2.47 and 2.68) at storage time. While, the $\mathrm{pH}$ in control, F3, and F4 remained relatively constant during the storage at $4{ }^{\circ} \mathrm{C}$, since the final $\mathrm{pH}$ recorded was $3.33,3.2$, and 3.3 , respectively. A free probiotic cell used carbohydrates and released small amounts of lactic acid, thus lowering the $\mathrm{pH}$ of the product during storage. Furthermore, some free cells did not survive at later stages of storage, although the lost probiotic cells could release enzymes for hydrolyzing sugars in the fruit nectar, thus lowering the $\mathrm{pH}$. These results demonstrated that microencapsulated probiotic bacteria create 
Table 4 Viability of free and encapsulated L. rhamnosus GG in strawberry nectar in simulated gastrointestinal conditions (SGC) during storage at 4 and $25{ }^{\circ} \mathrm{C}$ for 4 weeks (mean $\pm \mathrm{SD}$ )

\begin{tabular}{|c|c|c|c|c|c|c|}
\hline \multirow{2}{*}{$\begin{array}{l}\text { Storage time } \\
\text { (week) }\end{array}$} & \multirow{2}{*}{$\begin{array}{l}\text { Temperature } \\
\left({ }^{\circ} \mathrm{C}\right)\end{array}$} & \multirow[t]{2}{*}{ Formula } & \multicolumn{4}{|c|}{ Viable cell count $\left(\log _{10} \mathrm{CFU} \mathrm{mL} \mathrm{mL}^{-1}\right)$} \\
\hline & & & Time zero & After SGC $30 \mathrm{~min}$ & After SGC $120 \mathrm{~min}$ & After SGC $240 \mathrm{~min}$ \\
\hline \multirow[t]{10}{*}{0} & \multirow[t]{5}{*}{4} & $\mathrm{FC}$ & $7.72 \pm 0.14 \mathrm{aA}$ & $5.64 \pm 0.21 \mathrm{bC}$ & $4.32 \pm 0.1 \mathrm{cD}$ & $2.99 \pm 0.20 \mathrm{dE}$ \\
\hline & & F1 & $7.65 \pm 0.15 \mathrm{aA}$ & $6.34 \pm 0.11 \mathrm{bB}$ & $5.62 \pm 0.18 \mathrm{cC}$ & $4.83 \pm 0.11 \mathrm{dD}$ \\
\hline & & $\mathrm{F} 2$ & $7.70 \pm 0.09 \mathrm{aA}$ & $6.86 \pm 0.06 \mathrm{bB}$ & $6.66 \pm 0.11 \mathrm{bB}$ & $5.78 \pm 0.12 \mathrm{cC}$ \\
\hline & & F3 & $7.81 \pm 0.12 \mathrm{aA}$ & $7.46 \pm 0.16 \mathrm{aA}$ & $7.02 \pm 0.11 \mathrm{bA}$ & $6.96 \pm 0.12 \mathrm{cB}$ \\
\hline & & $\mathrm{F} 4$ & $7.78 \pm 0.19 \mathrm{aA}$ & $7.65 \pm 0.13 \mathrm{aA}$ & $7.68 \pm 0.19 \mathrm{aA}$ & $7.56 \pm 0.14 \mathrm{aA}$ \\
\hline & \multirow[t]{5}{*}{25} & $\mathrm{FC}$ & $7.72 \pm 0.14 \mathrm{aA}$ & $5.37 \pm 0.19 b C$ & $3.86 \pm 0.14 \mathrm{cE}$ & $2.26 \pm 0.25 \mathrm{dE}$ \\
\hline & & $\mathrm{F} 1$ & $7.65 \pm 0.15 \mathrm{aA}$ & $6.14 \pm 0.12 \mathrm{bB}$ & $4.94 \pm 0.09 \mathrm{cD}$ & $4.37 \pm 0.28 \mathrm{dD}$ \\
\hline & & $\mathrm{F} 2$ & $7.70 \pm 0.09 \mathrm{aA}$ & $6.49 \pm 0.15 \mathrm{bB}$ & $6.23 \pm 0.14 \mathrm{bB}$ & $5.35 \pm 0.22 \mathrm{cC}$ \\
\hline & & F3 & $7.81 \pm 0.12 \mathrm{aA}$ & $7.39 \pm 0.17 \mathrm{aA}$ & $6.74 \pm 0.18 \mathrm{bB}$ & $6.77 \pm 0.23 \mathrm{bB}$ \\
\hline & & $\mathrm{F} 4$ & $7.78 \pm 0.19 \mathrm{aA}$ & $7.44 \pm 0.10 \mathrm{aA}$ & $7.47 \pm 0.16 \mathrm{aA}$ & $7.33 \pm 0.14 \mathrm{aA}$ \\
\hline \multirow[t]{10}{*}{1} & \multirow[t]{5}{*}{4} & $\mathrm{FC}$ & $5.50 \pm 0.21 \mathrm{aC}$ & $4.24 \pm 0.17 \mathrm{bC}$ & $3.17 \pm 0.13 \mathrm{cD}$ & $2.41 \pm 0.21 \mathrm{dD}$ \\
\hline & & F1 & $6.53 \pm 0.13 \mathrm{aB}$ & $5.66 \pm 0.24 \mathrm{bB}$ & $4.27 \pm 0.12 \mathrm{cC}$ & $3.35 \pm 0.18 \mathrm{dD}$ \\
\hline & & $\mathrm{F} 2$ & $6.86 \pm 0.06 \mathrm{aB}$ & $6.65 \pm 0.14 \mathrm{aA}$ & $5.71 \pm 0.15 \mathrm{bB}$ & $4.94 \pm 0.10 \mathrm{cC}$ \\
\hline & & $\mathrm{F} 3$ & $7.41 \pm 0.17 \mathrm{aA}$ & $7.16 \pm 0.13 \mathrm{aA}$ & $6.74 \pm 0.15 \mathrm{bA}$ & $6.52 \pm 0.09 \mathrm{bB}$ \\
\hline & & $\mathrm{F} 4$ & $7.61 \pm 0.10 \mathrm{aA}$ & $7.4 \pm 0.27 \mathrm{aA}$ & $7.33 \pm 0.13 \mathrm{aA}$ & $7.19 \pm 0.16 \mathrm{aA}$ \\
\hline & \multirow[t]{5}{*}{25} & $\mathrm{FC}$ & $4.52 \pm 0.12 \mathrm{aD}$ & $3.13 \pm 0.08 \mathrm{bD}$ & $2.48 \pm 0.18 \mathrm{cE}$ & $1.68 \pm 0.12 \mathrm{dE}$ \\
\hline & & $\mathrm{F} 1$ & $5.47 \pm 0.14 \mathrm{aC}$ & $4.63 \pm 0.15 b C$ & $3.48 \pm 0.28 \mathrm{cD}$ & $2.68 \pm 0.14 \mathrm{dD}$ \\
\hline & & $\mathrm{F} 2$ & $5.99 \pm 0.26 \mathrm{aC}$ & $5.72 \pm 0.19 \mathrm{aB}$ & $4.78 \pm 0.2 \mathrm{bC}$ & $4.46 \pm 0.24 \mathrm{bC}$ \\
\hline & & F3 & $7.17 \pm 0.10 \mathrm{aA}$ & $6.62 \pm 0.21 \mathrm{aA}$ & $6.48 \pm 0.19 \mathrm{bA}$ & $6.33 \pm 0.18 \mathrm{bB}$ \\
\hline & & $\mathrm{F} 4$ & $7.45 \pm 0.11 \mathrm{aA}$ & $7.26 \pm 0.23 \mathrm{aA}$ & $7.2 \pm 0.07 \mathrm{aA}$ & $7.08 \pm 0.13 \mathrm{aA}$ \\
\hline \multirow[t]{10}{*}{2} & \multirow[t]{5}{*}{4} & $\mathrm{FC}$ & $4.52 \pm 0.12 \mathrm{aD}$ & $3.57 \pm 0.15 b C$ & $2.23 \pm 0.15 \mathrm{cC}$ & $1.75 \pm 0.17 \mathrm{dC}$ \\
\hline & & $\mathrm{F} 1$ & $5.69 \pm 0.18 \mathrm{aB}$ & $4.58 \pm 0.14 \mathrm{bB}$ & $2.45 \pm 0.21 \mathrm{cC}$ & $2.24 \pm 0.25 \mathrm{cB}$ \\
\hline & & $\mathrm{F} 2$ & $5.81 \pm 0.12 \mathrm{aB}$ & $4.79 \pm 0.12 \mathrm{bB}$ & $3.45 \pm 0.16 \mathrm{cB}$ & $2.86 \pm 0.31 \mathrm{~dB}$ \\
\hline & & F3 & $7.29 \pm 0.15 \mathrm{aA}$ & $7.08 \pm 0.09 \mathrm{aA}$ & $6.86 \pm 0.17 \mathrm{aA}$ & $6.68 \pm 0.12 \mathrm{aA}$ \\
\hline & & $\mathrm{F} 4$ & $7.42 \pm 0.07 \mathrm{aA}$ & $7.38 \pm 0.14 \mathrm{aA}$ & $7.12 \pm 0.09 \mathrm{aA}$ & $7.08 \pm 0.11 \mathrm{aA}$ \\
\hline & \multirow[t]{5}{*}{25} & $\mathrm{FC}$ & $2.43 \pm 0.21 \mathrm{aE}$ & $1.49 \pm 0.13 \mathrm{bD}$ & $0.51 \pm 0.11 \mathrm{cD}$ & $0 \pm 0 \mathrm{dD}$ \\
\hline & & $\mathrm{F} 1$ & $4.17 \pm 0.06 \mathrm{aC}$ & $3.59 \pm 0.16 b C$ & $2.57 \pm 0.15 \mathrm{cC}$ & $1.49 \pm 0.16 \mathrm{dC}$ \\
\hline & & $\mathrm{F} 2$ & $4.56 \pm 0.29 \mathrm{aC}$ & $4.27 \pm 0.22 \mathrm{aB}$ & $3.68 \pm 0.09 \mathrm{bB}$ & $2.54 \pm 0.19 \mathrm{cB}$ \\
\hline & & F3 & $7.16 \pm 0.08 \mathrm{aA}$ & $7.06 \pm 0.22 \mathrm{aA}$ & $6.8 \pm 0.1 \mathrm{aA}$ & $6.44 \pm 0.10 \mathrm{aA}$ \\
\hline & & F4 & $7.26 \pm 0.09 \mathrm{aA}$ & $7.18 \pm 0.08 \mathrm{aA}$ & $7.11 \pm 0.1 \mathrm{aA}$ & $7.03 \pm 0.16 \mathrm{aA}$ \\
\hline \multirow[t]{10}{*}{4} & \multirow[t]{5}{*}{4} & $\mathrm{FC}$ & $3.25 \pm 0.17 \mathrm{aD}$ & $2.58 \pm 0.12 \mathrm{bD}$ & $1.42 \pm 0.18 \mathrm{cC}$ & $0 \pm 0 \mathrm{dE}$ \\
\hline & & F1 & $4.49 \pm 0.14 \mathrm{aC}$ & $3.53 \pm 0.19 \mathrm{bC}$ & $2.26 \pm 0.09 \mathrm{cB}$ & $1.12 \pm 0.08 \mathrm{dC}$ \\
\hline & & F2 & $4.92 \pm 0.15 \mathrm{aC}$ & $3.82 \pm 0.17 b C$ & $2.67 \pm 0.15 \mathrm{cB}$ & $1.53 \pm 0.13 \mathrm{dC}$ \\
\hline & & F3 & $6.40 \pm 0.18 \mathrm{aB}$ & $6.23 \pm 0.11 \mathrm{aB}$ & $6.13 \pm 0.11 \mathrm{aA}$ & $6.11 \pm 0.08 \mathrm{aA}$ \\
\hline & & $\mathrm{F} 4$ & $7.25 \pm 0.12 \mathrm{aA}$ & $7.12 \pm 0.08 \mathrm{aA}$ & $6.84 \pm 0.19 \mathrm{aA}$ & $6.72 \pm 0.25 \mathrm{aA}$ \\
\hline & \multirow[t]{5}{*}{25} & $\mathrm{FC}$ & $1.65 \pm 0.16 \mathrm{aE}$ & $0 \pm 0 \mathrm{bE}$ & $0 \pm 0 \mathrm{bD}$ & $0 \pm 0 \mathrm{bE}$ \\
\hline & & $\mathrm{F} 1$ & $3.59 \pm 0.10 \mathrm{aD}$ & $2.28 \pm 0.17 \mathrm{bD}$ & $1.31 \pm 0.1 \mathrm{cC}$ & $0 \pm 0 \mathrm{dE}$ \\
\hline & & $\mathrm{F} 2$ & $3.77 \pm 0.14 \mathrm{aD}$ & $3.27 \pm 0.16 \mathrm{aC}$ & $2.25 \pm 0.15 \mathrm{bB}$ & $0.58 \pm 0.11 \mathrm{cD}$ \\
\hline & & F3 & $6.25 \pm 0.13 \mathrm{aB}$ & $6.07 \pm 0.05 \mathrm{aB}$ & $6.02 \pm 0.03 \mathrm{aA}$ & $5.71 \pm 0.08 \mathrm{bB}$ \\
\hline & & $\mathrm{F} 4$ & $7.12 \pm 0.07 \mathrm{aA}$ & $7.03 \pm 0.09 \mathrm{aA}$ & $6.77 \pm 0.12 \mathrm{aA}$ & $6.52 \pm 0.25 \mathrm{aA}$ \\
\hline
\end{tabular}

FC free cell (non-encapsulated), F1: alginate $2 \%+$ anthocyanin $0.1 \%+L$. rhamnosus GG), F2: alginate $2 \%+$ anthocyanin $0.1 \%+$ cocoa butter $1 \%+L$. rhamnosus GG, F3: alginate $2 \%+$ anthocyanin $0.1 \%+$ whey protein $3 \%+$ cocoa butter $1 \%+L$. rhamnosus GG, F4: alginate $2 \%+$ anthocyanin $0.1 \%+$ whey protein $2 \%+$ pullulan $2 \%+$ cocoa butter $1 \%+L$. rhamnosus GG. Same small letter indicates that there is no significant difference between any two means "in the same row" $(P>0.05)$. Same capital letter indicates that there is no significant difference between any two means "in the same column" $(P>0.05) . n=3$ 
Fig. 2 Changes in $\mathrm{pH}$ value of strawberry nectar supplemented with free and encapsulated $L$. rhamnosus GG during storage at (a) $4{ }^{\circ} \mathrm{C}$ and (b) $25^{\circ} \mathrm{C}$. Error bars indicate standard deviation $(n=3)$. Control: without probiotic cells, FC: free cells (non-encapsulated), F1: alginate $2 \%+$ anthocyanin $0.1 \%+L$. rhamnosus $\mathrm{GG}), \mathrm{F} 2$ : alginate $2 \%+$ anthocyanin $0.1 \%+$ cocoa butter $1 \%+$ L. rhamnosus GG), F3: alginate $2 \%+$ anthocyanin $0.1 \%+$ whey protein $3 \%+$ cocoa butter $1 \%+$ L. rhamnosus $\mathrm{GG})$, F4: alginate $2 \%+$ anthocyanin $0.1 \%+$ whey protein $2 \%+$ pullulan $2 \%+$ cocoa butter $1 \%+L$. rhamnosus GG)
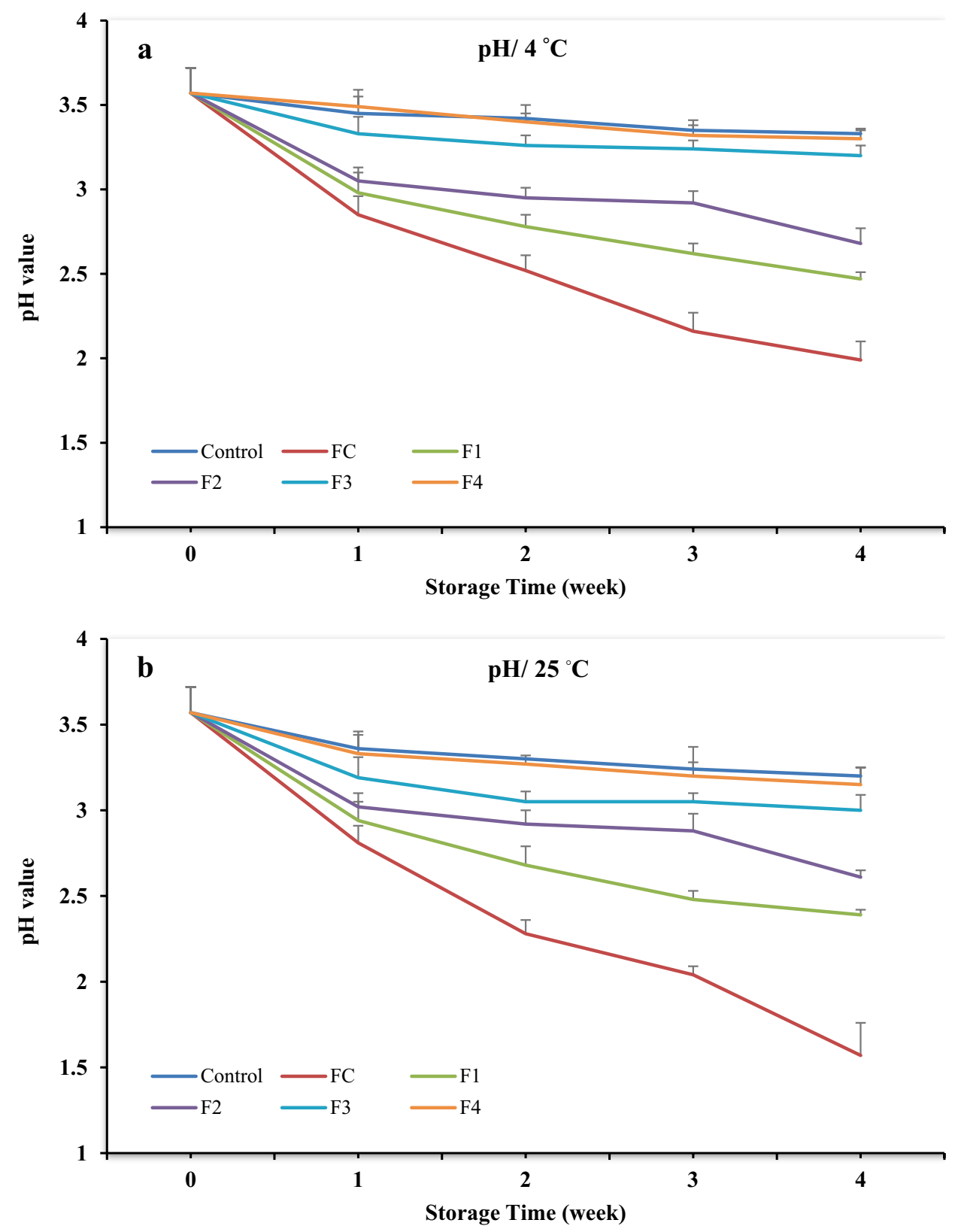

a stable acidic environment in strawberry nectar (Fig. 2a). Similar findings were reported by Kailasapathy (2006) in yogurts. The $\mathrm{pH}$ changes in control and different formulations of strawberry nectar stored at $25^{\circ} \mathrm{C}$ were a similar trend to those at $4{ }^{\circ} \mathrm{C}$ (Fig. 2b). While the nectar samples stored at $25{ }^{\circ} \mathrm{C}$ have more $\mathrm{pH}$ reduction than those stored at $4{ }^{\circ} \mathrm{C}$ (Gandomi et al., 2016).

\section{Anthocyanin Content}

As seen in Fig. 3, the total anthocyanin in strawberry (F. $\times$ ananassa, cultivar Camarosa) nectar at time zero was

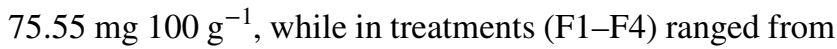
77.32 to $77.91 \mathrm{mg} 100 \mathrm{~g}^{-1}$. Generally, a significant reduction
$(P<0.05)$ was observed in the anthocyanin content in strawberry nectar after 4 weeks of storage. Total anthocyanin in strawberry nectar-containing free cells decreased to 61.77

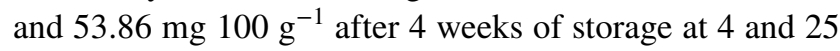
${ }^{\circ} \mathrm{C}$, respectively. While the anthocyanin of strawberry nectar containing formulations (F1, F2, and F3) significantly $(P<$ 0.05 ) showed a reduction of $6.75,4.89$, and $4.52 \mathrm{mg} 100$ $\mathrm{g}^{-1}$, respectively, F4 has a slight decline of $2.23 \mathrm{mg} 100 \mathrm{~g}^{-1}$ at storage time (Fig. 3a). Anthocyanin change would indicate that free probiotic cells used the sugars and produced lactic acid in the strawberry nectar if compared to cells that were trapped inside microcapsules. The total anthocyanin changes in the control sample and different formulations of strawberry nectar stored at $25{ }^{\circ} \mathrm{C}$ were in a similar trend to 
Fig. 3 Changes in total anthocyanin content in strawberry nectar supplemented with free and encapsulated L. rhamnosus GG during storage at (a) $4{ }^{\circ} \mathrm{C}$ and (b) $25^{\circ} \mathrm{C}$. Error bars indicate standard deviation $(n=3)$. Control: without probiotic cells, FC: free cells (non-encapsulated), F1: alginate $2 \%+$ anthocyanin $0.1 \%+L$ rhamnosus $\mathrm{GG}$ ), F2: alginate $2 \%+$ anthocyanin $0.1 \%+$ cocoa butter $1 \%+$ L. rhamnosus $\mathrm{GG}$ ), F3: alginate $2 \%+$ anthocyanin $0.1 \%+$ whey protein $3 \%+$ cocoa butter $1 \%+$ L. rhamnosus $\mathrm{GG}$ ), F4: alginate $2 \%+$ anthocyanin $0.1 \%+$ whey protein $2 \%+$ pullulan $2 \%+$ cocoa butter $1 \%+L$. rhamnosus $\mathrm{GG}$ )
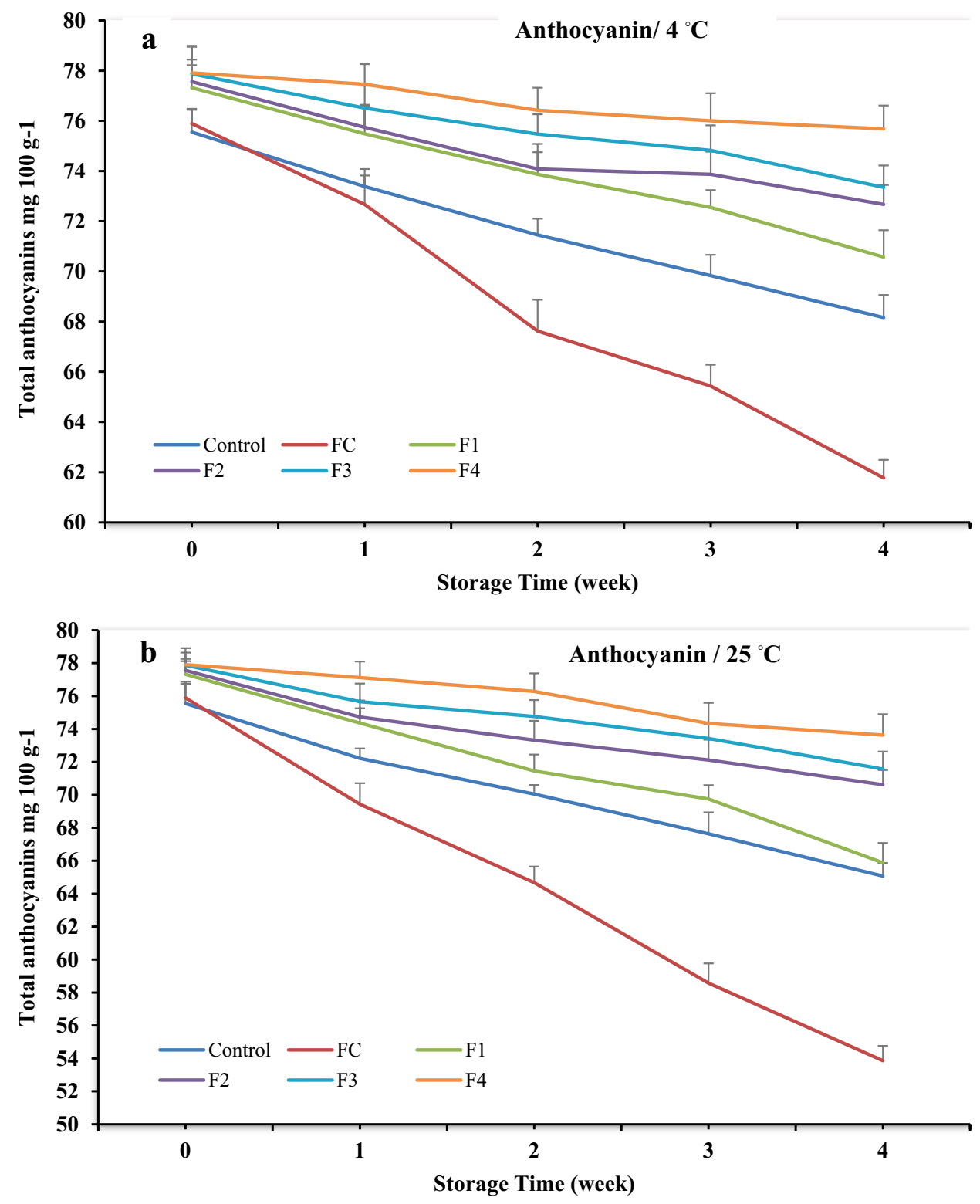

those at $4{ }^{\circ} \mathrm{C}$ (Fig. 3b). While the nectar samples stored at $25^{\circ} \mathrm{C}$ had more anthocyanin reduction than those stored at 4 ${ }^{\circ} \mathrm{C}$. Similar findings were reported in the previous study by Colín-Cruz et al. (2019) in blackberry juice. One study has established that probiotic culture produces hydrogen peroxide $\left(\mathrm{H}_{2} \mathrm{O}_{2}\right)$ at a safe level, but could accelerate the degradation of anthocyanin pigment and maybe controlled of the normal microflora (Felten et al., 1999).

\section{Sensory Evaluation and Questionnaire of Strawberry Nectar Fortified with Probiotic Microcapsules}

The sensory evaluation was based on a difference-preference test as exploratory and preliminary responses. The sensory properties, i.e., color, odor, taste, texture, and overall acceptability of the strawberry ( $F$. $\times$ ananassa, cultivar Camarosa) nectar containing free and encapsulated L. rhamnosus GG after 4 weeks of storage, were evaluated (Fig. 4). Results showed that probiotic microcapsules improved significantly all sensory characteristics $(P<0.05)$. The color scores decreased in FC and F1 samples with storage time; however, no significant difference $(P>0.05)$ was observed during the storage in formulations (F2-F4). It was noticed that the addition of red probiotic beads had a positive effect on the color of the strawberry nectar. This agrees with the previous report by Krasaekoopt and Kitsawad (2010) who found that the chitosan-alginate beads in fruit juices positively impacted its sensory parameters. Although whey protein-pullulanalginate beads were added to strawberry nectar samples, 
Fig. 4 Sensory evaluation parameters, i.e., (a) color, (b) odor, (c) taste, (d) texture, and (e) overall acceptability of strawberry nectar supplemented with free and encapsulated $L$. rhamnosus GG during 4-week storage at $4{ }^{\circ} \mathrm{C}(\mathrm{n}=10)$. (f) $\mathrm{A}$ questionnaire of 11-juice companies for fortified strawberry nectar with microencapsulated probiotic. Control: without probiotic cells, FC: free cells (non-encapsulated), F1: alginate $2 \%+$ anthocyanin $0.1 \%+L$. rhamnosus GG), F2: alginate $2 \%+$ anthocyanin $0.1 \%+$ cocoa butter $1 \%+L$. rhamnosus GG), F3: alginate $2 \%+$ anthocyanin $0.1 \%+$ whey protein $3 \%+$ cocoa butter $1 \%+L$. rhamnosus GG), F4: alginate $2 \%+$ anthocyanin $0.1 \%+$ whey protein $2 \%+$ pullulan $2 \%+$ cocoa butter $1 \%+L$. rhamnosus $\mathrm{GG}$ ) $\mathbf{a}$

\section{Color}

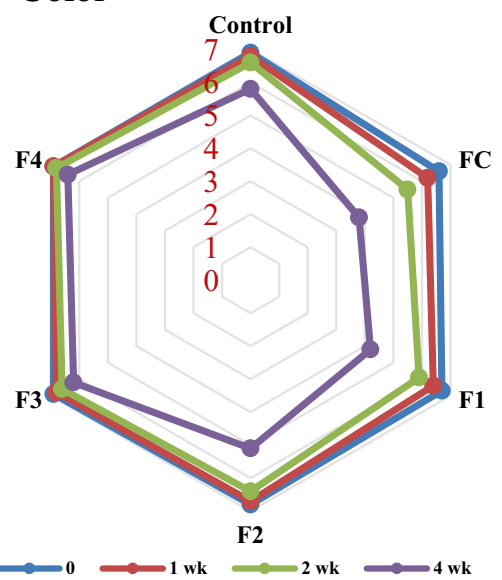

c

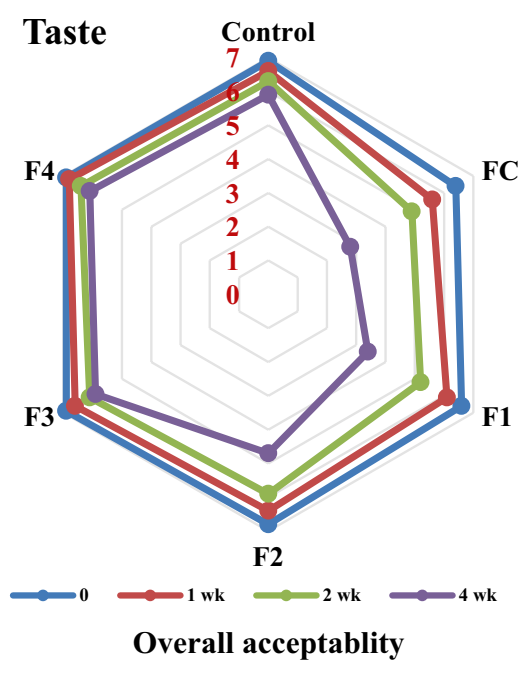

b Odor

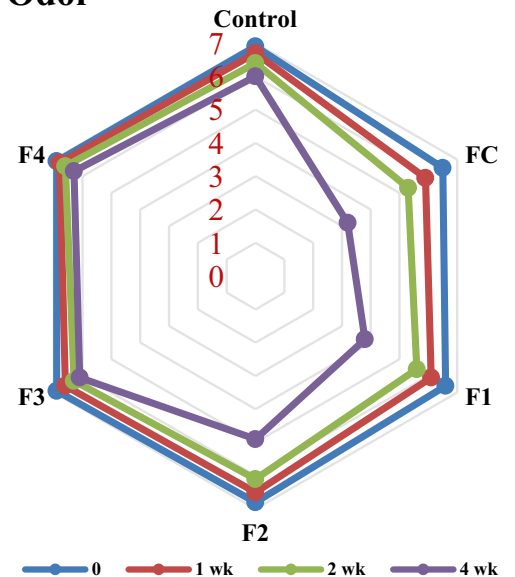

d

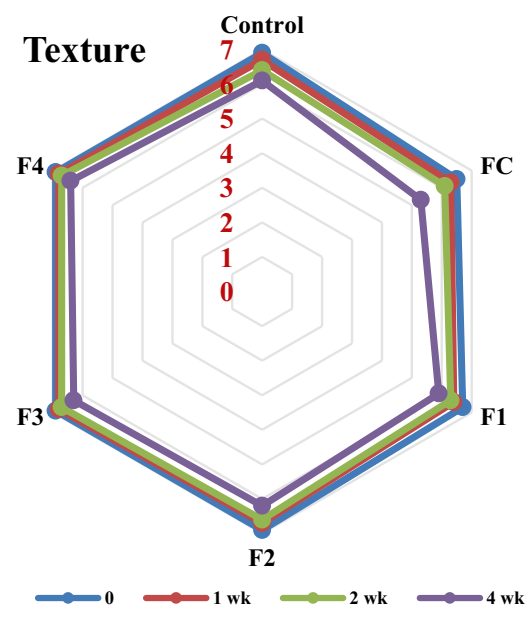

f

Juice Companies Questionnaire
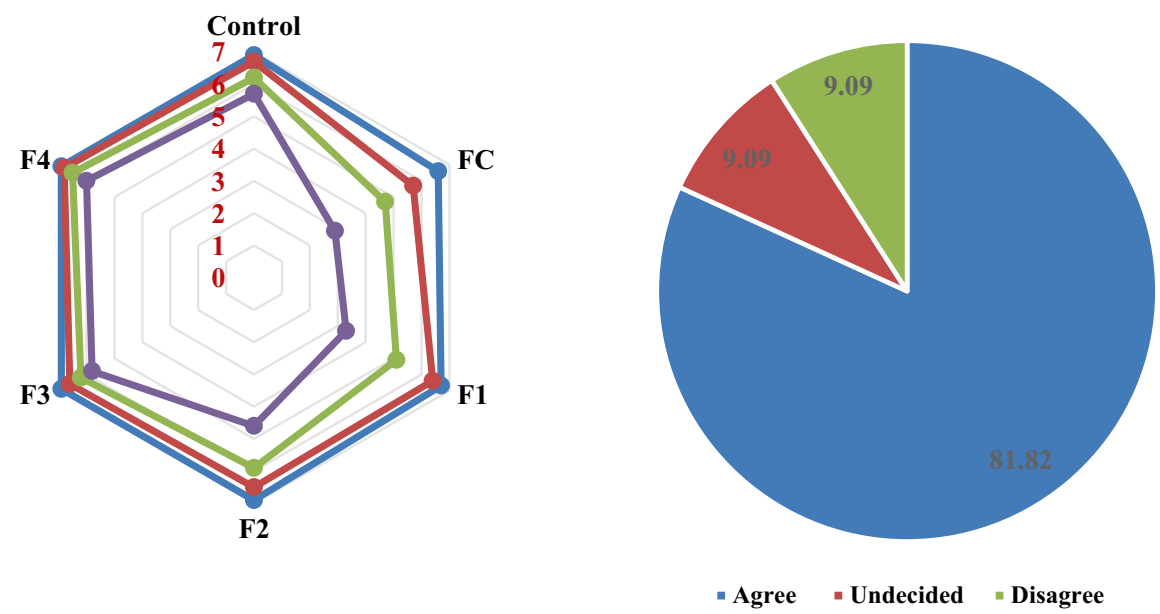

they remained invisible and made a better mouth feel for the panelists. A significant difference in odor and taste $(P<$ $0.05)$ was observed between FC treatment and formulations (F1-F4) in nectar samples. The strawberry nectar with free probiotic cells was scored to have sour, undesirable, and buttery flavor. It could be related to the fermentation metabolites produced from the free cells (Pimentel et al., 2015), while the microcapsules limit the acidification (Sohail et al., 2012). No significant difference $(P>0.05)$ in texture was recorded between all formulations (F1-F4). However, the overall acceptability of nectar samples substantially decreasing in FC, F1, and F2, the sensory compound's intensity reaches 
a plateau, indicated a possibility of rejection. While F3 and F4 were more accepted till the end of the storage period. These results were in agreement with Sohail et al. (2012) who reported that the addition of probiotic microcapsules (L. acidophilus NCFM and L. rhamnosus GG) in orange juice improved the sensory properties. Similar findings were reported by Krasaekoopt and Kitsawad (2010) in grape and orange juices, Gandomi et al. (2016) in apple juice. One study found that oligosaccharide extracts from Eleutherine americana have been proposed to keep the sensory scores of juices (Phoem et al., 2015). Another study by Fonseca et al. (2021) demonstrated that the probiotic L. plantarum CCMA 0743 strain confers unique sensory properties to passion fruit juice. According to the respondent of juice companies regarding strawberry nectar fortified with probiotic microcapsules (Fig. 4f), about $81.82 \%$ agreed, $9.09 \%$ undecided, and $9.09 \%$ disagreed. A significant difference in responses of juice companies $(P<0.05)$ was observed, but most juice companies agreed of fortified nectar because (i) encapsulated probiotic is a new approach in fruit nectar, (ii) enhances the functional properties of nectar, and (iii) develops novel products with acceptable characteristics. Based on sensory evaluation, questionnaire, and $\mathrm{pH}$, the strawberry nectar fortified with probiotic microcapsules (F4) was more accepted and stable during the storage period, as well as recommended applying in food products.

\section{Conclusions}

In conclusion, the probiotic L. rhamnosus GG cells were successfully microencapsulated using four alginate-whey protein-pullulan blends in a proper size, color, and shape. Results demonstrated that microencapsulation of L. rhamnosus $\mathrm{GG}$ had a higher survival rate during thermal (4 ${ }^{\circ} \mathrm{C}$ and $72{ }^{\circ} \mathrm{C}$ ), juice additives (chemical materials), and gastrointestinal (intestinal juice) treatments compared to the free bacterial cell. All formulations exhibited high encapsulation efficiency ( $>89 \%)$, medium bead size (406-504 $\mu \mathrm{m}$ ), and proper color (red color). F4 (alginate $2 \%+$ anthocyanin $0.1 \%+$ whey protein $2 \%+$ pullulan $2 \%+$ cocoa butter $1 \%+$ L. rhamnosus $\mathrm{GG})$ showed the greatest viability $\left(7 \log \mathrm{CFU} \mathrm{mL} \mathrm{m}^{-1}\right)$ in nectar during storage. A significant decrease $(P<0.05)$ in $\mathrm{pH}$ and anthocyanin values was observed in strawberry $(F . \times$ ananassa, cultivar Camarosa) nectar including free cells. The nectar samples fortified with probiotic microcapsules exhibited high sensory scores (difference-preference test as exploratory and preliminary responses) up to 4 weeks, while those included free probiotic cells were rejected (fermented flavor). The questionnaire response showed highly accepted in commercial companies (> 80\% agreed). However, more research is needed to evaluate the sensory parameters by consumer acceptance tests and questionnaires on a large scale, as well as a feasibility study of fortified nectar. In general, the results demonstrated that the strawberry nectar may be used as an appropriate vehicle for delivering encapsulated probiotic cells to humans.

Acknowledgements MKM is thankful to Dr. Cutter, Professor of Food Science at Pennsylvania State University for providing pullulan.

Funding Open access funding provided by The Science, Technology \& Innovation Funding Authority (STDF) in cooperation with The Egyptian Knowledge Bank (EKB).

Data Availability The datasets supporting the conclusions of this article are included within the article and its additional files.

\section{Declarations}

Conflict of Interest The authors declare no competing interests.

Open Access This article is licensed under a Creative Commons Attribution 4.0 International License, which permits use, sharing, adaptation, distribution and reproduction in any medium or format, as long as you give appropriate credit to the original author(s) and the source, provide a link to the Creative Commons licence, and indicate if changes were made. The images or other third party material in this article are included in the article's Creative Commons licence, unless indicated otherwise in a credit line to the material. If material is not included in the article's Creative Commons licence and your intended use is not permitted by statutory regulation or exceeds the permitted use, you will need to obtain permission directly from the copyright holder. To view a copy of this licence, visit http://creativecommons. org/licenses/by/4.0/.

\section{References}

Afzaal, M., Khan, A. U., Saeed, F., Ahmed, A., Ahmad, M. H., Maan, A. A., Tufail, T., Anjum, F. M., \& Hussain, S. (2019). Functional exploration of free and encapsulated probiotic bacteria in yogurt and simulated gastrointestinal conditions. Food Science \& Nutrition, 7(12), 3931-3940.

Alvarez-Suarez, J. M., Cuadrado, C., Redondo, I. B., Giampieri, F., González-Paramás, A. M., \& Santos-Buelga, C. (2021). Novel approaches in anthocyanin research-plant fortification and bioavailability issues. Trends in Food Science \& Technology, In press.

Anand, S., Beniwal, A., Singh, K. S., \& Aggarwal, D. (2018). Significance of probiotic encapsulation and deficiencies within. The Pharma Innovation Journal, 7(1), 434-439.

AOAC. (2016). Official methods of analysis (20th ed.). Association of Official Analytical Chemists.

Bampi, G. B., Backes, G. T., Cansian, R. L., de Matos, F. E., Ansolin, I. M. A., Poleto, B. C., Corezzolla, L. R., \& Favaro-Trindade, C. S. (2016). Spray chilling microencapsulation of Lactobacillus acidophilus and Bifidobacterium animalis subsp. lactis and its use in the preparation of savory probiotic cereal bars. Food and Bioprocess Technology, 9(8), 1422-1428.

Belwal, T., Singh, G., Jeandet, P., Pandey, A., Giri, L., Ramola, S., Bhatt, I. D., Venskutonis, P. R., Georgiev, M. I., \& Clément, C. 
(2020). Anthocyanins, multi-functional natural products of industrial relevance: recent biotechnological advances. Biotechnology Advances, 107600.

Bilenler, T., Karabulut, I., \& Candogan, K. (2017). Effects of encapsulated starter cultures on microbial and physicochemical properties of traditionally produced and heat treated sausages (sucuks). LWTFood Science and Technology, 75, 425-433.

Bosnea, L. A., Moschakis, T., \& Biliaderis, C. G. (2014). Complex coacervation as a novel microencapsulation technique to improve viability of probiotics under different stresses. Food and Bioprocess Technology, 7(10), 2767-2781.

Boudou, T., Crouzier, T., Ren, K., Blin, G., \& Picart, C. (2010). Multiple functionalities of polyelectrolyte multilayer films: New biomedical applications. Advanced Materials, 22(4), 441-467.

Celli, G. B., Ghanem, A., \& Brooks, M.S.-L. (2015). Bioactive encapsulated powders for functional foods-a review of methods and current limitations. Food and Bioprocess Technology, 8(9), $1825-1837$.

Chaikham, P. (2015). Stability of probiotics encapsulated with Thai herbal extracts in fruit juices and yoghurt during refrigerated storage. Food Bioscience, 12, 61-66.

Chávarri, M., Marañón, I., \& Villarán, M.C. (2012). Encapsulation technology to protect probiotic bacteria. Probiotics. IntechOpen.

Codex. (2005). General standard for fruit juices and nectars Codex Alimentarius Commission. Codex Standard, 247.

Colín-Cruz, M., Pimentel-González, D., Carrillo-Navas, H., AlvarezRamírez, J., \& Guadarrama-Lezama, A. (2019). Co-encapsulation of bioactive compounds from blackberry juice and probiotic bacteria in biopolymeric matrices. LWT-Food Science and Technology, 110, 94-101.

Costabile, A., Bergillos, T., Rasinkangas, P., Korpela, K., De Vos, W., \& Gibson, G. R. (2017). Effect of soluble corn fibre with Lactobacillus rhamnosus GG and the pilus-deficient derivative GG-PB12 on faecal microbiota, immune function and metabolism in healthy elderly (Saimes study). Frontiers in Immunology, 8, 1443.

Dafe, A., Etemadi, H., Dilmaghani, A., \& Mahdavinia, G. R. (2017). Investigation of pectin/starch hydrogel as a carrier for oral delivery of probiotic bacteria. International Journal of Biological Macromolecules, 97, 536-543.

de Araújo Etchepare, M., Nunes, G. L., Nicoloso, B. R., Barin, J. S., Flores, E. M. M., de Oliveira Mello, R., \& de Menezes, C. R. (2020). Improvement of the viability of encapsulated probiotics using whey proteins. LWT-Food Science and Technology, 117, 108601.

de Oliveira Vieira, K. C., Ferreira, C. D. S., Bueno, E. B. T., De Moraes, Y. A., Toledo, A. C. C. G., Nakagaki, W.R., Pereira, V.C., \& Winkelstroter, L.K. (2020). Development and viability of probiotic orange juice supplemented by Pediococcus acidilactici CE51. LWT-Food Science and Technology, 130, 109637.

De Prisco, A., van Valenberg, H. J., Fogliano, V., \& Mauriello, G. (2017). Microencapsulated starter culture during yoghurt manufacturing effect on technological features. Food and Bioprocess Technology, 10(10), 1767-1777.

Ding, W., \& Shah, N. P. (2008). Survival of free and microencapsulated probiotic bacteria in orange and apple juices. International Food Research Journal, 15(2), 219-232.

dos Santos, D. X., Casazza, A. A., Aliakbarian, B., Bedani, R., Saad, S. M. I., \& Perego, P. (2019). Improved probiotic survival to in vitro gastrointestinal stress in a mousse containing Lactobacillus acidophilus La-5 microencapsulated with inulin by spray drying. $L W T$ Food Science and Technology, 99, 404-410.

El Kadri, H., Lalou, S., Mantzouridou, F., \& Gkatzionis, K. (2018). Utilisation of water-in-oil-water (W1/O/W2) double emulsion in a set-type yogurt model for the delivery of probiotic Lactobacillus paracasei. Food Research International, 107, 325-336.
Fan-Chiang, H. J., \& Wrolstad, R. E. (2005). Anthocyanin pigment composition of blackberries. Journal of Food Science, 70(3), C198-C202.

Felten, A., Barreau, C., Bizet, C., Lagrange, P. H., \& Philippon, A. (1999). Lactobacillus species identification, $\mathrm{H} 2 \mathrm{O} 2$ production, and antibiotic resistance and correlation with human clinical status. Journal of Clinical Microbiology, 37(3), 729-733.

Fonseca, H.C., de Sousa Melo, D., Ramos, C.L., Menezes, A.G.T., Dias, D.R., \& Schwan, R.F. (2021). Sensory and flavor-aroma profiles of passion fruit juice fermented by potentially probiotic Lactiplantibacillus plantarum CCMA 0743 strain. Food Research International, 110710.

Gandomi, H., Abbaszadeh, S., Misaghi, A., Bokaie, S., \& Noori, N. (2016). Effect of chitosan-alginate encapsulation with inulin on survival of Lactobacillus rhamnosus GG during apple juice storage and under simulated gastrointestinal conditions. LWT-Food Science and Technology, 69, 365-371.

Giuffrè, A. (2013). HPLC-DAD detection of changes in phenol content of red berry skins during grape ripening. European Food Research and Technology, 237(4), 555-564.

Giuffrè, A. M., Zappia, C., \& Capocasale, M. (2017). Physicochemical stability of blood orange juice during frozen storage. International Journal of Food Properties, 20(sup2), 1930-1943.

González-Ferrero, C., Irache, J. M., Marín-Calvo, B., Ortiz-Romero, L., Virto-Resano, R., \& González-Navarro, C. J. (2020). Encapsulation of probiotics in soybean protein-based microparticles preserves viable cell concentration in foods all along the production and storage processes. Journal of Microencapsulation, 37(3), 242-253.

Gounga, M., Xu, S. Y., Wang, Z., \& Yang, W. (2008). Effect of whey protein isolate-pullulan edible coatings on the quality and shelf life of freshly roasted and freeze-dried chinese chestnut. Journal of Food Science, 73(4), E155-E161.

Gralec, M., Wawer, I., \& Zawada, K. (2019). Aronia melanocarpa berries: phenolics composition and antioxidant properties changes during fruit development and ripening. Emirates Journal of Food and Agriculture, 214-221.

Guerin, D., Vuillemard, J.-C., \& Subirade, M. (2003). Protection of bifidobacteria encapsulated in polysaccharide-protein gel beads against gastric juice and bile. Journal of Food Protection, 66(11), 2076-2084.

Haghighatpanah, N., Mirzaee, H., Khodaiyan, F., Kennedy, J. F., Aghakhani, A., Hosseini, S. S., \& Jahanbin, K. (2020). Optimization and characterization of pullulan produced by a newly identified strain of Aureobasidium pullulans. International Journal of Biological Macromolecules, 152, 305-313.

Hao, F., Fu, N., Ndiaye, H., Woo, M. W., Jeantet, R., \& Chen, X. D. (2021). Thermotolerance, survival, and stability of lactic acid bacteria after spray drying as affected by the increase of growth temperature. Food and Bioprocess Technology, 14(1), 120-132.

Kailasapathy, K. (2006). Survival of free and encapsulated probiotic bacteria and their effect on the sensory properties of yoghurt. LWT-Food Science and Technology, 39(10), 1221-1227.

Kailasapathy, K. (2009). Encapsulation technologies for functional foods and nutraceutical product development. CAB Reviews: Perspectives in Agriculture Veterinary Science Nutrition and Natural Resources, 4(033), 1-19.

Karimi, R., Mortazavian, A. M., \& Da Cruz, A. G. (2011). Viability of probiotic microorganisms in cheese during production and storage: A review. Dairy Science \& Technology, 91(3), 283-308.

Khorasani, S. N., Ataei, S., \& Neisiany, R. E. (2017). Microencapsulation of a coconut oil-based alkyd resin into poly (melamineurea-formaldehyde) as shell for self-healing purposes. Progress in Organic Coatings, 111, 99-106. 
Krasaekoopt, W., \& Kitsawad, K. (2010). Sensory characteristics and consumer acceptance of fruit juice containing probiotics beads in Thailand. AU Journal of Technology, 14(1), 33-38.

Krasaekoopt, W., Pianjareonlap, R., \& Kittisuriyanont, K. (2008). Survival of probiotics in fruit Juices during refrigerated storage. Thai Journal of Biotechnology, 8(1), 129-133.

Krasaekoopt, W., \& Watcharapoka, S. (2014). Effect of addition of inulin and galactooligosaccharide on the survival of microencapsulated probiotics in alginate beads coated with chitosan in simulated digestive system, yogurt and fruit juice. LWT-Food Science and Technology, 57(2), 761-766.

Lai, K. W., How, Y. H., \& Pui, L. P. (2020). Storage stability of microencapsulated Lactobacillus rhamnosus GG in hawthorn berry tea with flaxseed mucilage. Journal of Food Processing and Preservation, e14965.

Liu, S., Li, Y., \& Li, L. (2017). Enhanced stability and mechanical strength of sodium alginate composite films. Carbohydrate Polymers, 160, 62-70.

Ma, J., Xu, C., Yu, H., Feng, Z., Yu, W., Gu, L., Liu, Z., Chen, L., Jiang, Z., \& Hou, J. (2021). Electro-encapsulation of probiotics in gum Arabic-pullulan blend nanofibres using electrospinning technology. Food Hydrocolloids, 111, 106381.

Malmo, C., La Storia, A., \& Mauriello, G. (2013). Microencapsulation of Lactobacillus reuteri DSM 17938 cells coated in alginate beads with chitosan by spray drying to use as a probiotic cell in a chocolate soufflé. Food and Bioprocess Technology, 6(3), 795-805.

MarketsandMarkets. (2018). Probiotics market by application (functional food \& beverages [dairy, non-dairy beverages, baked goods, meat, cereals], dietary supplements, animal feed), source (bacteria, yeast), form (dry, liquid), end user (human, animal), and region-global forecast to 2022. India: MarketsandMarkets Pvt Ltd Pune. https://www.marketsandmarkets.com/MarketReports/probiotic-market-advanced-technologies-and-globalmarket-69.html

Mays, Z. J., \& Nair, N. U. (2018). Synthetic biology in probiotic lactic acid bacteria: At the frontier of living therapeutics. Current Opinion in Biotechnology, 53, 224-231.

MedveĎová, A., Liptáková, D., \& Valík, L. (2008). Characterization of the growth of Lactobacillus rhamnosus GG in milk at suboptimal temperatures. Journal of Food \& Nutrition Research, 47(2), 60-67.

Mokarram, R., Mortazavi, S., Najafi, M. H., \& Shahidi, F. (2009). The influence of multi stage alginate coating on survivability of potential probiotic bacteria in simulated gastric and intestinal juice. Food Research International, 42(8), 1040-1045.

Mokhtari, S., Khomeiri, M., Jafari, S. M., Maghsoudlou, Y., \& Ghorbani, M. (2017). Descriptive analysis of bacterial profile, physicochemical and sensory characteristics of grape juice containing Saccharomyces cerevisiae cell wall-coated probiotic microcapsules during storage. International Journal of Food Science \& Technology, 52(4), 1042-1048.

Morales, A., Carvajal, P., Silva, N., Hernandez, M., Godoy, C., Rodriguez, G., Cabello, R., Garcia-Sesnich, J., Hoare, A., \& Diaz, P. I. (2016). Clinical effects of Lactobacillus rhamnosus in non-surgical treatment of chronic periodontitis: A randomized placebo-controlled trial with 1-year follow-up. Journal of Periodontology, 87(8), 944-952.

Morsy, M. K., \& Elsabagh, R. (2021). Quality parameters and oxidative stability of functional beef burgers fortified with microencapsulated cod liver oil. LWT-Food Science and Technology, 142(110959), $1-10$

Moumita, S., Goderska, K., Johnson, E. M., Das, B., Indira, D., Yadav, R., Kumari, S., \& Jayabalan, R. (2017). Evaluation of the viability of free and encapsulated lactic acid bacteria using in-vitro gastro intestinal model and survivability studies of synbiotic microcapsules in dry food matrix during storage. LWT-Food Science and Technology, 77, 460-467.
Murúa-Pagola, B., Castro-Becerra, A. L., Abadía-García, L., CastañoTostado, E., \& Amaya-Llano, S. L. (2021). Protective effect of a cross-linked starch by extrusion on the survival of Bifidobacterium breve ATCC 15700 in yogurt. Journal of Food Processing and Preservation, 45(1), e15097.

Nami, Y., Lornezhad, G., Kiani, A., Abdullah, N., \& Haghshenas, B. (2020). Alginate-Persian gum-prebiotics microencapsulation impacts on the survival rate of Lactococcus lactis ABRIINW-N19 in orange juice. $L W T, 124,109190$.

Østlie, H. M., Treimo, J., \& Narvhus, J. A. (2005). Effect of temperature on growth and metabolism of probiotic bacteria in milk. International Dairy Journal, 15(10), 989-997.

Pereda, M. S. B., Nazareno, M. A., \& Viturro, C. I. (2020). Optimized formulation of a Physalis peruviana $\mathrm{L}$. fruit nectar: physicochemical characterization, sensorial traits and antioxidant properties. Journal of Food Science and Technology, 1-11.

Phoem, A. N., Chanthachum, S., \& Voravuthikunchai, S. P. (2015). Applications of microencapsulated Bifidobacterium longum with Eleutherine americana in fresh milk tofu and pineapple juice. Nutrients, 7(4), 2469-2484.

Pimentel, T. C., Madrona, G. S., \& Prudencio, S. H. (2015). Probiotic clarified apple juice with oligofructose or sucralose as sugar substitutes: Sensory profile and acceptability. LWT-Food Science and Technology, 62(1), 838-846.

Praepanitchai, O. -A., Noomhorm, A., \& Anal, A. K. (2019). Survival and behavior of encapsulated probiotics (Lactobacillus plantarum) in calcium-alginate-soy protein isolate-based hydrogel beads in different processing conditions ( $\mathrm{pH}$ and temperature) and in pasteurized mango juice. BioMed research international, 2019.

Rather, S. A., Akhter, R., Masoodi, F., Gani, A., \& Wani, S. (2017). Effect of double alginate microencapsulation on in vitro digestibility and thermal tolerance of Lactobacillus plantarum NCDC201 and L casei NCDC297. LWT-Food Science and Technology, 83, $50-58$.

Rodrigues, D., Sousa, S., Gomes, A. M., Pintado, M. M., Silva, J. P., Costa, P., Amaral, M. H., Rocha-Santos, T., \& Freitas, A. C. (2012). Storage stability of Lactobacillus paracasei as free cells or encapsulated in alginate-based microcapsules in low $\mathrm{pH}$ fruit juices. Food and Bioprocess Technology, 5(7), 2748-2757.

Salehi, F. (2020). Physicochemical characteristics and rheological behaviour of some fruit juices and their concentrates. Journal of Food Measurement and Characterization, 14, 2472-2488.

Shinde, T., Sun-Waterhouse, D., \& Brooks, J. (2014). Co-extrusion encapsulation of probiotic lactobacillus acidophilus alone or together with apple skin polyphenols: An aqueous and valueadded delivery system using alginate. Food and Bioprocess Technology, 7(6), 1581-1596.

Sohail, A., Turner, M. S., Coombes, A., \& Bhandari, B. (2013). The viability of Lactobacillus rhamnosus GG and Lactobacillus acidophilus NCFM following double encapsulation in alginate and maltodextrin. Food and Bioprocess Technology, 6(10), 2763-2769.

Sohail, A., Turner, M. S., Prabawati, E. K., Coombes, A. G., \& Bhandari, B. (2012). Evaluation of Lactobacillus rhamnosus GG and Lactobacillus acidophilus NCFM encapsulated using a novel impinging aerosol method in fruit food products. International Journal of Food Microbiology, 157(2), 162-166.

Steel, R., Torrie, J., \& Dickey, D. (1980). Principles and procedures of statistics (p. 633). Mc-Graw Hill Book Co., Inc.

Sun, H., Zhang, M., Liu, Y., Wang, Y., Chen, Y., Guan, W., Li, X., \& Wang, Y. (2021). Improved viability of Lactobacillus plantarum embedded in whey protein concentrate/pullulan/trehalose hydrogel during freeze drying. Carbohydrate Polymers, 260, 117843.

Su, J., Wang, X., Li, W., Chen, L., Zeng, X., Huang, Q., \& Hu, B. (2018). Enhancing the viability of lactobacillus plantarum as probiotics through encapsulation with high internal phase emulsions 
stabilized with whey protein isolate microgels. Journal of Agricultural and Food Chemistry, 66(46), 12335-12343.

Suriano, S., Balconi, C., Valoti, P., \& Redaelli, R. (2021). Comparison of total polyphenols profile anthocyanins color analysis carotenoids and tocols in pigmented maize. LWT, 144, 111257.

Tripathi, M. K., \& Giri, S. K. (2014). Probiotic functional foods: Survival of probiotics during processing and storage. Journal of Functional Foods, 9, 225-241.

Van der Merwe, D., Bosman, M., \& Ellis, S. (2014). Consumers' opinions and use of food labels: Results from an urban-rural hybrid area in South Africa. Food Research International, 63, 100-107.

Vasile, M. A., Milea, ȘA., Enachi, E., Barbu, V., Cîrciumaru, A., Bahrim, G. E., Râpeanu, G., \& Stănciuc, N. (2020). Functional enhancement of bioactives from black beans and lactic acid bacteria into an innovative food ingredient by comicroencapsulation. Food and Bioprocess Technology, 13, 978-987.

Vemmer, M., \& Patel, A. V. (2013). Review of encapsulation methods suitable for microbial biological control agents. Biological Control, 67(3), 380-389.

Xu, M., Gagné-Bourque, F., Dumont, M.-J., \& Jabaji, S. (2016). Encapsulation of Lactobacillus casei ATCC 393 cells and evaluation of their survival after freeze-drying storage and under gastrointestinal conditions. Journal of Food Engineering, 168, 52-59.

Xu, L., Xu, Z., \& Liao, X. (2021). A review of fruit juice authenticity assessments: targeted and untargeted analyses. Critical Reviews in Food Science and Nutrition, 1-22.

Yasmin, I., Saeed, M., Pasha, I., \& Zia, M. A. (2019). Development of whey protein concentrate-pectin-alginate based delivery system to improve survival of B. longum BL-05 in simulated gastrointestinal conditions. Probiotics and antimicrobial proteins, 11(2), 413-426.

Yildiz, G., \& Aadil, R. M. (2020). Comparison of high temperatureshort time and sonication on selected parameters of strawberry juice during room temperature storage. Journal of Food Science and Technology, 57(4), 1462-1468.

Yousuf, B., Gul, K., Wani, A. A., \& Singh, P. (2016). Health benefits of anthocyanins and their encapsulation for potential use in food systems: A review. Critical Reviews in Food Science and Nutrition, 56(13), 2223-2230.

Zeashan, M., Afzaal, M., Saeed, F., Ahmed, A., Tufail, T., Ahmed, A., \& Anjum, F. M. (2020). Survival and behavior of free and encapsulated probiotic bacteria under simulated human gastrointestinal and technological conditions. Food Science \& Nutrition, 8(5), 2419-2426.

Zhang, L., Chen, X. D., Boom, R. M., \& Schutyser, M. A. (2018). Survival of encapsulated Lactobacillus plantarum during isothermal heating and bread baking. LWT-Food Science and Technology, 93, 396-404.

Zhang, Y., Lin, J., \& Zhong, Q. (2015). The increased viability of probiotic Lactobacillus salivarius NRRL B-30514 encapsulated in emulsions with multiple lipid-protein-pectin layers. Food Research International, 71, 9-15.

Publisher's Note Springer Nature remains neutral with regard to jurisdictional claims in published maps and institutional affiliations. 